\title{
Agglomeration Tendencies in EU Regions: Where Does Capital Go?
}

\author{
Claudia Stirboeck \\ Centre for European Economic Research (ZEW), Mannheim, Germany
}

April, 2001

\begin{abstract}
This paper focuses on two aspects being neglected in the analysis of agglomeration tendencies so far. First, it regards regional agglomeration patterns and secondly, the allocation of capital across industrial sectors. Indeed, the average relative concentration of capital turns out to be of a higher level and variability than the one of employment in 1985-94. Regions marked by a relatively high uneven allocation of capital are also subject to lower economic performance than regions marked by a relatively low capital concentration. Though direct investments in services represent a large share of direct investments in the 1990s, relative specialisation in services is rather low, but steadily increasing from 1985-94 in EU countries and regions.
\end{abstract}

JEL classification: E 22, F 21, R 30

Keywords: Regional Economics, Direct Investment, Capital Allocation, Factor Mobility

Claudia Stirboeck

\section{ZEW}

PO Box 103443

D-68034 Mannheim

Tel.: +49-621-1235-218

Fax: +49-621-1235-223

E-Mail: stirboeck@zew.de 


\section{Non-technical summary}

For half a century Europe has been underlying a process of economic integration which has been enforced enormously in the last decade. It still remains unanswered if this process leads to increased industrial agglomeration in some regions due to e.g. the realisation of economies of scale or enforces uniform regional allocation of industrial sectors due to e.g. higher intraindustrial trade. This topic is of particular interest for politicians and economists in the EU. More flexible regional policies will be needed insofar as economic regions showing a rather heterogeneous industrial structure find themselves confronted with the risk of economic shocks being intra-regionally un-smoothable.

The in the course of EU integration increasingly mobile production factor capital, neglected in the empirical studies on agglomeration so far, is subject of this study. Its focus is on measures of relative regional specialisation and regional concentration using standardised Ginicoefficients. Exceptional is the use first of capital data and second of regional data in addition to national data in this empirical analysis.

Though decreasing, the on average highest sectoral concentration of direct investment (DI) can be found in the Netherlands and Germany while Italy and France show the lowest levels of concentration. With regard to the concentration of gross fixed capital formation (GFCF) in EU countries, the two countries having the highest degree of relative concentration are Luxembourg and Ireland followed by the UK. In addition, Greece and Portugal prove to be highly concentrated regarding a number of different indicators of recent studies.

Comparing both sorts of capital data, the level of concentration of DI is on average higher than the GFCF concentration level for the respectively available countries. European integration does not seem to have had a particular intra-European effect on factor allocation so far as there is no difference to be found between intra-EU and extra-EU stocks of DI inflows. The new focus on capital, however, empirically turns out to be very important as employment is found to be on average allocated more uniformly than capital what is particularly evident at the national level. Variability of the regional levels of concentration are less sharp for employment than for capital. In addition, the level of employment concentration is either constant or decreasing (Portugal and Spain) while increasing levels of capital concentration are evident in Ireland (for GFCF) and the UK (for FDI). These results support the hypothesis that due to its higher mobility capital might substitute for employment and catch concentration processes inside EU to a larger extent.

In most countries or regions specialisation indices for services are, though not outstanding, steadily increasing between 1985-94. As the importance of services has constantly been increasing inside EU in the 1990s, further agglomeration effects are to be expected due to the ongoing market liberalisation. In addition, many regions show an increasing capital concentration in the beginning of the 1990s, the time of the inauguration of the Single Market, what might also be a sign of further increasing concentration.

In a descriptive analysis higher concentrated regions could be found to be of poorer economic performing than lower concentrated regions with respect to unemployment rate, number of patents, total regional GDP and total regional GFCF. Causal relationships, though, remain to be detected in further empirical analyses. However, the fact that the peripheral regions are often highly concentrated and of poorer economic performance than core regions, stresses the importance of EU and EU countries not to neglect their focus on the economic development of peripheral regions. 


\section{Introduction}

Since 1951 Europe has gone through a process of economic integration which has been enforced enormously in the last decade. On the one hand, great advantages are expected for everyone: lower prices through higher competitive pressure, extension of markets linked with increased product variety for consumers and larger economies of scale for firms. However, in a world of imperfect competition, "love of variety" of consumers as well as technology and knowledge spillovers firms might need to concentrate production in few places in order to remain competitive.

Such agglomeration processes are the subject of a number of models of the "New Economic Geography". The seminal model by Krugman (1991) theoretically confirming the possibility of core-periphery-tendencies includes two regions, two sectors (agriculture and manufacture), and employment (agricultural and industrial workers) as the only production factor ${ }^{1}$. In his study, Krugman takes regional development in the US as an example for what is to be expected in the EU. While EMU-countries represent a group of countries being monetarily integrated for a rather short period of time with the process of integration still going on, the US have constituted a monetary union for a long time. Krugman found a noticeably stronger employment concentration across industrial sectors in US-regions than in the four biggest EU countries. Krugman therefore predicts increasing specialisation for a further economically integrated Europe.

This potential national or regional concentration in a few industrial sectors is of particular interest for politicians and economists in the EU as the predicted concentration process is leading to a greater need of flexible regional policies while in many fields the competence in economic policy is transferred to the EU level. Economic regions showing a rather heterogeneous industrial structure could find themselves confronted with the risk of economic shocks being intra-regionally un-smoothable. Our study focuses on EU regions because this field has been neglected so arr $^{2}$.

Insights into the level of concentration of regions across industrial sectors can be gained by the calculation of different indices of concentration. A very common index is the Ginicoefficient. In addition to the direct use of output or of trade data ${ }^{3}$, it is possible to look at the

Financial support of the Volkswagen-Stiftung within the project No. II/76547 is gratefully acknowledged. The author would like to thank Simone Giloth for excellent research assistance, Mr. Scholz of the German Bundesbank for providing us with the German regional FDI data, and Herbert S. Buscher, Jürgen Kähler and Michael Schröder for helpful comments. All remaining errors, however, are my own.

${ }^{1}$ A number of extended or improved models have been published since 1991. Krugman (1998) e.g. gives a short overview on the development of the theoretical analysis. However, the seminal model of Krugman (1991) is still accepted to be kind of a general basic model.

${ }^{2}$ Exceptions are the very recent studies of Güßefeldt and Streit (2000) analysing the variation in economic development of EU regions, of Tirado, Paluzie and Pons (2000) and of Kalemli-Ozcan, Sorensen and Yosha (1999) concentrating on production specialisation in Spanish regions (in the $19^{\text {th }}$ century) and in Italian, Spanish and UK regions respectively.

${ }^{3}$ Trade data can be regarded to give insights into the specialisation of an economy insofar as the patterns of trade approximately reflect the structure of its production. 
allocation of the most important factors of production: labour and capital. In the first empirical analyses regarding agglomeration tendencies in the US as well as in the EU, however, the allocation of the production factor capital is rarely looked at.

However, there are important reasons not to neglect capital when regarding EU regions. The further integration of the European (capital) markets within the EU and EMU might be a trigger for a new allocation of production factors. This is particularly relevant for capital while the mobility of employment remains restricted to a much larger extent by national borders, social transfer and security systems as well as cultural and language barriers. The low mobility of labour across EU countries is in sharp contrast to the high mobility of US employees across states. Results on concentration tendencies for US states which are based on employment data can therefore not easily be extended to EU countries or regions. Instead, the allocation of capital might reflect specialisation or concentration tendencies much better as there are (although limited) possibilities of substitution between these two factors. It is therefore possible that the higher mobility of capital replaces the movement of employment (particularly in the EU) and that the allegedly low level of employment concentration in the EU found by recent studies is a result of this. However, even in case of perfect labour mobility, employment and capital can be differently concentrated due to substitution possibilities.

Interregional mobility of capital within countries is not a recent phenomena, but European integration has increasingly, though so far still not completely, liberalised international capital movements (European Commission, 2000). This analysis therefore includes data on foreign direct investment (DI), i.e. internationally mobile capital, and data on gross fixed capital formation (GFCF), covering foreign as well as domestic investment. Only the latter directly reflects agglomeration levels. As DI inflows might enforce agglomeration tendencies or can simply substitute for national capital having no net effect on agglomeration, both data have to be interpreted separately.

This study aims at the examination of possible agglomeration tendencies of capital in EU countries and, especially, EU regions that might be enforced by EMU. Its purpose is to give insight into the economic characteristics of strongly specialised or concentrated regions which are assumed to be exposed to a higher risk of asymmetric regional shocks.

Recent developments of foreign direct investment inflows into EU countries are summarised in chapter II. Then, existing empirical results of concentration tendencies in EU countries are presented in chapter III. In the empirical part in chapter IV, Gini-coefficients not only of EU countries, but also of EU regions are calculated on the basis of - so far neglected - DI and GFCF data. The results of this new empirical analysis are compared with those of recent studies on national agglomeration tendencies using trade, production and employment data. Finally, the focus is on the comparison of the results found at the national and the regional level as well as on the detailed analysis of the pattern of regional concentration processes. However, neither the question of allocative gains nor the one of the adequate implementation of regional stabilisation policy in case of asymmetric shocks is considered in this study. 


\section{Capital Flows in the EU}

World-wide, the importance of direct investment activity and international firms is increasing sharply. In 1998, foreign affiliate sales (of goods and services) were more important than international trade (\$11 versus \$7 trillion) (United Nations, 1999: XIX). The data on FDI stocks show that - not surprisingly - foreign activity in developed countries dominates in services while it concentrates on manufacturing in developing countries - though, in the 1990s DI in services increased in both at the extent of the FDI decrease in the primary sector. The largest part of direct investment activity takes place in developed countries, in particular in the Triad, about $80 \%$ of outflows coming from only 10 large home countries ${ }^{4}$.

Even though the increase in greenfield investment was high in 1999, the increase in mergers and acquisitions (M\&A) - driving the rise of FDI - was stronger (OECD, 2000). M\&A concentration in Western Europe is most prominent in the telecom industry and the chemicals sector. Extra-EU outflows in manufacturing largely exceeded inflows while the importance of services in intra-EU FDI went up, to some extent due to liberalisation and privatisation measures. The largest share in manufacturing FDI inflows in 1995-96 was reached by the chemicals industry, while in the services sectors financial intermediation, other business activities as well as trade \& repairs were most prominent (OECD, 2000). It therefore can be expected that the services sectors are of great importance in the analysis of concentration tendencies in the EU.

At the end of 1996, the major partners of the EU with respect to FDI positions were the US, Switzerland and Australia concerning outflows and the US, Switzerland and Japan concerning inflows. However about $52 \%$ of the total assets of EU member states were held inside other member states at that time (Eurostat, 1998). The growth of FDI inflows to the EU was of a great magnitude in 1991 - with a share of $50 \%$ of world DI inflows in 1991 (United Nations, 1999:38) - and had largely gone down in 1993. The single market programme seems to have had its greatest impact on FDI inflows before 1992 anticipating effective market integration. According to the United Nations (1999:40) "the anticipatory effects of EMU on FDI turned out to be less impressive [...]" taking into consideration the years prior to 1999. However, after the inauguration of the monetary union, inflows into the EMU markedly increased (from 91.8 in 1998 to 166.3 billion euro in 1999). While DI inflows have been low compared to outflows prior to the EMU, it seems as if the EMU lead to their soaring which renders the question of their geographic allocation particularly important. Net DI into the EMU even reached a large positive value from January to August 2000. However, this was only due to a large DI inflow into the telecommunications sector in Germany. The acquisition of Mannesmann by the British and extra-EMU telecommunications group Vodafone led to an inflow of about 138 billion euro. Without this specific inflow, net EMU-DI from January to August 2000 would only have amounted to about -65 billion euro (compared to -120.6 billion euro in 1999).

\footnotetext{
${ }^{4}$ However, taking their economic size into account, developing countries receive more investment inflows in percent of GDP than developed countries do. Only regarding the developing countries, FDI inflows in real estate and chemicals are most important (United Nations, 1999).
} 
A detailed look at IMF data on DI in EU member countries reveals that a number of them (the UK, the Netherlands, Italy, Germany, France and most of the time Finland as well) are strong net DI exporters with relatively low DI inflows. Comparably high DI inflows are to be found in four countries in the 1990s, however, at different times. Prior to the installation of the single market on January $1^{\text {st }}$, 1993 , capital flows to Spain and Portugal had been most pronounced, but have been decreasing since 1992. Since 1998, DI outflows have even surmount their inflows. Austria, joining the EU in 1995, has been subject to high DI inflows since 1993. Ireland, instead, member since 1973, has been marked by rocketing inflows since 1998. Ireland successfully applied regional economic policies with the EU structural fund receipts and therefore attracted large international investors particularly in computer businesses, electronic commerce, financial services as well as large call-centres.

In economic research, the determinants of these DI flows are often discussed ${ }^{5}$ but are still not conclusive. Two of the rare studies focusing on capital data in the analysis of regional concentration processes were conducted on behalf of the European Commission and concentrate on the effects of the single market programme. The analysis of the effects of the EMU on capital allocation, though, remains a subject for further research. The first study (European Commission, 1998a) observes labour as well as direct investment data concentrating solely on the Objective I "regions" Spain, Portugal, Greece, and Ireland as well as Southern Italy. By using of a qualitative indicator analysis, regional and sectoral investment trends are illustrated. However, no common effect of the single market programme on direct investments in these countries can be found. In addition, no clear effect e.g. on factor allocation is demonstrable empirically within the framework of a growth model. While e.g. Portugal shows a trend towards concentration of direct investments and employment, the opposite development seems to be taking place in Spain. The second study (European Commission, 1998b) finds only small evidence for industrial concentration for 1984-92 in a descriptive analysis of four countries. An econometric analysis of direct investment decisions of German and British firms confirms a positive effect of the single market on the extent of direct investments (especially in the financial sector) which is stronger for British than for German firms.

The fact that the impact of the single market programme is stronger for direct investments than for labour (European Commission, 1998a) is a strong indication for the empirical relevance of capital flows in agglomeration and supports the view that the mobility of capital plays a more important role than the one of labour with regard to possible agglomeration tendencies in the EU. In the following an overview is given on the empirical evidence found so far on such tendencies.

\footnotetext{
${ }^{5}$ United Nations (1992) provided a survey of the determinants of DI while Caves (1996) gives an overview on the theory of multinational enterprises. Recent empirical macroeconomic studies use gravity models - known from the analysis of trade flows - in explaining the determinants by ex- and import countries' GDP as well as economic distance as the most important variables. Examples are Brenton, DiMauro and Lücke (1998) as well as Bajo-Rubio and Sosvilla-Rivero (1994) with respect to DI in Spain. Additional variables found to have an influence on DI are economies of scale, the exchange rate, the Single European Act, inflation rate, trade barriers as well as the DI stock abroad.
} 


\section{Recent empirical evidence of agglomeration tendencies}

For the coming years, Eurostat (1999) expects an increase in population in nearly all regions of Ireland, Luxembourg, Denmark, and the Netherlands as well as in most regions of Sweden and Great Britain ${ }^{6}$ whereas some regions in Greece, Great Britain, and especially Eastern Germany as well as many parts of Spain and Italy will be confronted with a decrease in population. In the 1990s, the regions with the sharpest decreases in population were found in Eastern Germany as well as the Southern European regions Alentejo/Portugal, Liguria/Italy, Pais Vasco/Spain, and Rioja/Spain. And, in fact, we will see later that the peripheral regions are the ones with the most uneven allocation of capital across industrial sectors.

In general, it can be stated that population increases faster in wealthy regions and that regions with decreasing population are marked by a high proportion of elderly people (Eurostat, 1999). However, this focus on population development is not sufficient in order to assess the extent of regional agglomeration. Thus the concentration of production and the allocation of production factors has to be included in the economic analysis. In the following, an overview on existing studies on the concentration of employment, trade, and production is given.

Regarding concentration tendencies, the focus can first be on the allocation of one sector across a number of regions and second be on the concentration of different sectors within a single region. A measure of sectoral concentration regards the degree of uneven allocation of capital of one sector across the regions considered and hence to what extent sectors are concentrated in countries or regions. This study instead focuses on regional development and the measurement of regional concentration, i.e. the allocation of different industrial sectors within a region and hence, to what extent a country or region is specialised in certain sectors.

In addition, measures of concentration can be divided into measures of absolute concentration and measures of relative concentration in comparison to an economy of reference or the average sectoral structure of all regional entities included. Both ways of measuring concentration have to be differentiated as one industry can in absolute terms be allocated equally across a group of regions, while some regions have specialised particularly in this industrial sector and others have not. It is the unequal size of regions or countries that causes the difference between the absolute and the relative concentration index. While measures of absolute concentration $^{7}$ underlie some influence of regional or sectoral classification which is inconsistent or unequal in size, measures of relative concentration are influenced by the concentration patterns of either the economy of reference or the average pattern of the group of countries included. In case of a very special pattern of the reference economy, the relative specialisation pattern of the economic entities analysed will be biased. Examples of relative concentration

\footnotetext{
${ }^{6}$ However, in the long-term perspective (25 years), Eurostat expects a slowdown or even decrease in population growth in Europe.

${ }^{7}$ One example of a measure of absolute concentration is the Herfindahl index: $\sum_{i}^{n}\left(s_{i j}\right)^{2}$ with $s_{i j}$ being the share of industry $\mathrm{i}$ in all industries of region $\mathrm{j}$. The index ranges between $1 / \mathrm{n}$ (uniform distribution of industrial shares) and 1 (high concentration, totally different from uniform distribution, i.e. complete specialisation in one industry).
} 
are the Balassa-Aquino index, the coefficient of conformity, the Finger-Kreinin index as well as the Gini-index. According to Krieger-Boden (1999), who conducted a systematic comparison of concentration indices, the Gini-coefficient as well as the Finger-Kreinin index are the most adequate measures for our focus of analysis.

The Balassa-Aquino index is defined as

$$
\sqrt{\sum_{i} r_{i}\left(\frac{s_{i j}}{r_{i}}-1\right)^{2}}
$$

with $s_{i j}$ being the share of industry i (e.g. in form of production, employment, or - as in our case - in form of capital) in all industries of region $\mathrm{j}$ and $r_{i}$ the share of industry $\mathrm{i}$ in all industries of the reference economy (being either a specified economy or the average structure of e.g. the European Union). The index is, in contrast to most other concentration measures, not restricted to range between 0 and 1 and thus rather difficult to be interpreted or compared in economic analysis.

The coefficient of conformity is calculated in the following way:

$$
\frac{\sum_{i} s_{i j} r_{i}}{\sqrt{\left(\sum_{i} s_{i j}^{2}\right)\left(\sum_{i} r_{i}^{2}\right)}}
$$

However, it differentiates insufficiently within its range as it gives a nearly identical relative concentration pattern even in case of rather different structures (Krieger-Boden, 1999:246).

The bilateral Finger-Kreinin index between region $\mathrm{j}$ and the reference economy is defined as ${ }^{8}$ :

$$
\sum_{i} \min \left(s_{i j}, r_{i}\right)
$$

It is, in contrast to the first two measures, able to class broadly between 0 and 1 and to differentiate well similar and dissimilar structures. However, it has to be paid attention to the fact that variations in production shares of small countries or regions (and such variation can easily be relatively large) can have a relatively strong influence on the value of the FK-index. As the average of bilateral FK-indices between the region in focus and the other regions in the sample ${ }^{9}$ usually is the measure of concentration of interest, this effect is reduced.

${ }^{8}$ The Finger-Kreinin index can be transformed into the so-called "specialisation coefficient" which sometimes is also used in the literature.

${ }^{9}$ The average Finger-Kreinin index of region $\mathrm{j}$ is defined as $\frac{\sum_{k} \sum_{i} \min \left(s_{i j}, s_{i k}\right)}{m}$ with $\mathrm{k}$ being all regions
besides $\mathrm{j}$ and $\mathrm{m}$ the total number of all regions besides $\mathrm{j}$. 
The Gini-coefficient is well known from the analysis of problems of distribution ${ }^{10}$. It can be used to focus on either relative or absolute concentration depending on the precise construction of industrial shares whose distribution is analysed (see below). It gives strong weight to the middle parts of the distribution of sectoral shares. As a consequence, changes in industrial sectors with very similar relative industrial shares have a larger effect on the value of the Gini-coefficient than changes in industrial sectors at the outer sides of the distribution (Cowell, 1995). However, the coefficient's range between 0 (low concentration) and 1 (high concentration) usually reflects well differences in the level of concentration. Therefore, the Ginicoefficient is the most widely used concentration index in the analysis of regional patterns.

\section{Recent empirical analyses}

The empirical analysis of US regions (as well as 4 EU countries) by Krugman (1991) is based on employment data. Krugman's concentration measure is an adapted Gini-coefficient used to measure the geographical concentration of employment in several industrial sectors relative to the employment concentration in other countries. Nevertheless, the author does not prove that a single money and goods market leads to an increasingly augmenting regional concentration of all sectors. The analysis of 106 US industrial sectors points on the one hand to an intensified regional concentration of low-tech industries (overall textile-related industries) ${ }^{11}$, on the other hand it also demonstrates that the overall concentration of sectors has decreased during the period from 1947 to 1985 . Other authors also find no continuous or general long run trend towards sectoral agglomeration with respect to employment data in the US. Kim (1995) analysed the development of the industrial structure of the US between 1860 and 1987. The highest locational concentration seems to have occurred in the 1920s. Accordingly, US industries have been confronted by decreasing specialisation since the 1930s and until the 1980s.

Similar analyses with employment data of European countries have been conducted by Brülhart (1998) for the period 1961 to 1990 for 11 countries and 18 industrial sectors (using a 2digit level of disaggregation according to the OECD industrial classification) as well as by Klüver and Rübel (1998) for 1972 and 1992 comparing 13 countries and 52 industrial sectors (using a 3-digit level of disaggregation of the same classification). Brülhart (1998) finds a reinforcement of industrial specialisation in European countries in the 1980s. The author concludes that the process of concentration is already more advanced in the high-technological and scale-intensive sectors than in labour-intensive and science-based sectors - the latter now showing stronger tendencies of specialisation. Regarding the extent of specialisation of individual countries calculated by Klüver and Rübel (1998), an increasing divergence of industrial structure can be found in Europe as well - except for Portugal, Finland and Belgium ${ }^{12}$.

\footnotetext{
${ }^{10}$ The Gini-coefficient is expressed as the ratio of twice the area between the Lorenz curve and the $45^{\circ}-$ line. The Lorenz curve is constructed by plotting the cumulated relative sectoral shares in descending order.

${ }^{11}$ Krugman (1991: 59), however, points to the fact that many traditional (and small) industries are rated by their own three-digit code while new (e.g. high-technological) industries are often rated in unspecified aggregates. This might have largely influenced the results. Thus, Krugman concludes that he does not find hightechnological sectors not to be concentrated, but low-technological sectors to be also highly clustered.

${ }^{12}$ Klüver and Rübel (1998), however, concentrated on sectoral concentration and found that the general concentration of all industrial sectors has risen by $23.53 \%$ while the one of resource-intensive and scale-intensive
} 
The study of regional concentration in the EU by Amiti (1999) is an example of an analysis based not only on employment data, but also on production data from UNIDO ${ }^{13}$. It shows for both, employment and production data, the consistently highest levels of concentration in Greece and Portugal and the lowest ones in France and the UK followed by Germany which corresponds to the results found by Klüver and Rübel (1998). According to Amiti (1999) industrial specialisation has strongly increased between 1968 and 1990 in Belgium, Denmark, Germany, Greece, Italy as well as the Netherlands, while it has gone down in France, Spain and Great Britain. Portugal, Spain, and the UK show no significant change. However, in the 1980s, concentration has been reinforced in all countries ${ }^{14}$.

According to the new theory of international trade, convergence of the structure of production should reinforce intraindustrial trade (i.e. exchange of products of the same sector), while industrial concentration or specialisation is supposed to intensify the classical interindustrial trade (i.e. exchange of products of different industrial sectors) ${ }^{15}$. A study conducted on behalf of the European Commission (European Commission, 1997) is based on an analysis of external trade data for the period from 1980 to 1994. It demonstrates that since the mid-1980s a rise in intraindustrial trade can be found regarding intra-EU trade. The development of trade structures shows that in this period of time agglomeration tendencies are not present as, except for Ireland and Denmark, the share of interindustrial trade did not increase. The absolute share of interindustrial trade, however, proves to be extremely high in Ireland, Denmark, Portugal, and Greece.

Sapir (1996) analyses the "four largest" EU countries' national exports. By use of the Herfindahl index he measures trade specialisation for the period from 1977 to 1992 and finds a constantly low degree of specialisation in Germany, Italy, and the UK. Only in France, this low level of specialisation has markedly increased after 1986. The calculation of Lawrence indices of structural change based on export data additionally reveals little structural change, only the year 1986 showing a significantly higher rate of structural change than the average change.

sectors has only gone up by $3.34 \%$ and $9.84 \%$ respectively and the one of science-based and labour-intensive sectors by $51.83 \%$ and $73.81 \%$ respectively.

${ }^{13}$ Eurostat data has been used by Amiti (1999) as well, but the calculated Gini-coefficients are not given in the paper, so we refer to the UNIDO data results here.

${ }^{14}$ Haaland et al. (1999) also using production data conducted a comparison of sectoral concentration in the EU of the years 1992 and 1985. Using two modified versions of the Hoover-Balassa index, the authors differentiate between a measure of concentration relative to the average spread of industrial activities among countries and a measure capturing concentration in absolute terms. In both years railroad equipment, transport equipment n.e.c., footwear, leather, aircraft, and pottery \& china were among the most - relatively - concentrated sectors EU-wide, while plastic products n.e.c., metal products and iron \& steel were rather dispersed. The concentration strongly increased by $11.4 \%$ in these 7 years - most strongly in drugs \& medicines as well as chemicals excluding drugs. A number of sectors (motor vehicles, electrical apparatus n.e.c., machinery \& equipment n.e.c., radio, TV \& communication equipment, and office \& computing machinery) were concentrated in absolute but not in relative terms, i.e. these industries were localised in large countries. Other industries (textiles, wearing apparel, and railroad equipment) were instead more pronounced in smaller countries being only relatively concentrated.

${ }^{15}$ However, this assumes that the development of production and trade is symmetric. In contrast to this assumption would be the extreme, but possible, case that a change in e.g. consumption is completely absorbed by the adaptation of exports while production stagnates. 
Greenaway and Hine (1991) measure intra-industry trade (IIT) by the widely used GrubelLloyd index and the Michaely index correcting for the downward bias of the Grubel-Lloyd index. The results point at an increase in intra-industry trade between 1970-85 which was weaker towards the end of the period analysed having reached a high level of IIT. The patterns of import similarity hardly changed while the export patterns show an increasing diversity of exports which is equivalent to higher intra-industry trade.

\section{Comparison of production, trade and employment data}

Table 1 gives a detailed comparison of the results of the above summarised recent studies on regional concentration and its respective level. Most countries show low or intermediate levels of concentration with respect to employment, trade and production data. Portugal and Greece seem to be highly concentrated when regarding the structure of trade but only at an intermediate level with regard to the allocation of employment and production. In addition, Denmark and Ireland show a high level of concentration in trade according to the EC's 1997 analysis.

Table 1: Comparison of recent results on regional agglomeration, own systematisation

\begin{tabular}{|c|c|c|c|c|c|c|c|c|c|c|c|c|c|}
\hline Country & $A$ & B & $\mathrm{D}$ & $\mathrm{E}$ & $\mathrm{F}$ & $G$ & $\mathrm{H}$ & I & $\mathrm{L}$ & $\mathrm{N}$ & $\mathrm{P}$ & $S$ & $\mathrm{U}$ \\
\hline $\begin{array}{l}\text { UNIDO employment data } \\
\text { 1980-90 (Amiti, 1999) }\end{array}$ & - & $\mathrm{L}$ & $\begin{array}{l}\text { L- } \\
\mathrm{I}\end{array}$ & - & $\mathrm{L}$ & $\mathrm{L}$ & I & $\mathrm{L}$ & - & $\mathrm{L}$ & I & $\mathrm{L}$ & $\mathrm{L}$ \\
\hline $\begin{array}{ll}\text { UNIDO production data } \\
1980-90 \text { (Amiti, 1999) }\end{array}$ & - & $\mathrm{L}$ & I & - & $\mathrm{L}$ & $\mathrm{L}$ & I & $\mathrm{L}$ & - & $\mathrm{L}$ & I & $\mathrm{L}$ & $\mathrm{L}$ \\
\hline $\begin{array}{l}\text { Interindustrial trade }(\mathrm{Eu}- \\
\text { rostat data, 1980-94) } \\
\text { (EC, } \\
\end{array}$ & - & $\begin{array}{l}\text { L- } \\
\text { I }\end{array}$ & $\mathrm{H}$ & $\mathrm{H}$ & $\begin{array}{l}\text { L- } \\
\text { I }\end{array}$ & $\begin{array}{l}\text { L- } \\
\text { I }\end{array}$ & $\mathrm{H}$ & I & $\begin{array}{l}\text { L- } \\
\mathrm{I}\end{array}$ & I & $\mathrm{H}$ & I & $\begin{array}{l}\text { L- } \\
\text { I }\end{array}$ \\
\hline \multicolumn{14}{|c|}{ Intra-Industrial-Trade (level of diversification, not concentration): } \\
\hline $\begin{array}{l}\text { OECD Export data } 1970-85 \\
\text { (Greenaway\&Hine, } \\
\text { Michaely measure) }\end{array}$ & $\begin{array}{l}\mathrm{I}- \\
\mathrm{H}\end{array}$ & $\begin{array}{l}\mathrm{I}- \\
\mathrm{H}\end{array}$ & I & I & $\mathrm{H}$ & $\mathrm{H}$ & $\mathrm{L}$ & I & |- & I & $\begin{array}{l}\text { I- } \\
\text { L }\end{array}$ & $\begin{array}{l}\mathrm{I}- \\
\mathrm{H}\end{array}$ & $\mathrm{H}$ \\
\hline $\begin{array}{l}\text { OECD Im- and Export data } \\
\text { 1970-85 (Greenaway\&Hine, } \\
\text { 1991, Grubel-Lloyd index) }\end{array}$ & $\begin{array}{l}\mathrm{I}- \\
\mathrm{H}\end{array}$ & $\mathrm{H}$ & I & I & $\mathrm{H}$ & $\mathrm{I}$ & $\mathrm{L}$ & I & - & $\begin{array}{l}\mathrm{I}- \\
\mathrm{H}\end{array}$ & $\begin{array}{l}\mathrm{L}- \\
\mathrm{I}\end{array}$ & I & $\mathrm{H}$ \\
\hline
\end{tabular}

Countries: A=Austria, $\mathrm{B}=$ Belgium, $\mathrm{D}=$ Denmark, $\mathrm{E}=$ Ireland, $\mathrm{F}=$ France, $\mathrm{G}=$ Germany, $\mathrm{H}=$ Greece, I=Italy, $\mathrm{L}=$ Luxembourg, N=Netherlands, $\mathrm{P}=$ Portugal, $\mathrm{S}=$ Spain, $\mathrm{U}=\mathrm{UK}$.

Level of concentration with respect to average Gini-coefficients: $L=$ low $(<0.3)$, I=intermediate (0.3-0.5), $\mathrm{H}=$ high (>0.5); levels for trade indicators according to the respective, differing range (for the Michaely and the Grubel-Lloyd index, boundary values are 0.5 and 0.8 ). For the trade indicators, interim cases are marked as such. Those cases are shaded which reflect a high degree of concentration.

A comparison of the level of specialised, inter-industrial trade of the EC-study and the level of diversified intra-industrial trade of the Greenaway and Hine-study reflects a high level of concentration in Greece and Portugal by a simultaneously low level of intra-industrial trade and high level of interindustrial trade in these two countries. In addition, Denmark and Spain are marked by strong interindustrial trade activities. To conclude, the direct focus on output concentration by Amiti (1999) leads to the result of mostly increasing concentration in the industrial sectors in the EU in contrast to the findings of the European Commission (1997) 
which point at an increasing product diversification on the basis of trade flows. Regarding labour force, agglomeration has led to a similar picture as the focus on output structure so far.

However, this focus is restricted as it only pays attention to a single production factor. These contradictory results on regional developments by use of different agglomeration indicators demand as explained above further research. This study will, therefore, focus on the allocation of the traditionally more mobile production factor capital which has been neglected in the empirical studies so far.

\section{Allocation of capital in EU countries and regions: a compari- son of FDI and investment concentration across industries}

In the recent literature, the Gini-coefficient has often been used as a measure of regional as well as of sectoral concentration ${ }^{16}$ and that has proved to be an adequate measure for the analysis of relative concentration processes (see above). Therefore, the relative geographical concentration of sectoral FDI stocks and GFCF is analysed using Gini-coefficients in the following ${ }^{17}$. The Gini-coefficient ranges from 0 to $(n-1) / n$ with $n$ being the number of sectors. It is equal to 0 when all sectors have the same size (e.g. all have an equal number of employees), and it is the higher the more concentrated e.g. employment is. This means that 0 stands for uniform allocation and (n-1)/n for absolute concentration of the respective economic variable considered.

Relative regional concentration can be calculated by the use of relative specialisation indices of the defined industrial sectors in a country (a region). The latter are constructed by dividing the share of a country's (region's) sectoral FDI (GFCF) in national (regional) FDI (GFCF) by the share of all EU countries' (the respective national) sectoral FDI (GFCF) in total EU (national) FDI (GFCF). By this, relative specialisation indices are defined $\operatorname{as}^{18}$ :

$$
B_{i j}=\frac{s_{i j}}{r_{i j}}=\frac{\frac{x_{i j} x_{i j}}{\sum_{j} x_{i j}}}{\sum_{i} \sum_{j} x_{i j}} \quad \text { with } \mathrm{i}=\text { sector index and } \mathrm{j}=\text { country index. }
$$

${ }^{16}$ See for example the studies of geographical concentration by Krugman (1991), Brülhart (1998), Klüver and Rübel (1998), as well as Amiti (1999). Sapir (1996) analysing absolute country specialisation with export data made use of the Herfindahl index instead, Greenaway and Hine (1991) of the Grubel-Lloyd, the Michaely as well as the Finger-Kreinin index. Kalemli-Ozcan, Sorensen and Yosha (1999) used a variancelike measure given their focus on risk-sharing.

${ }^{17}$ To check for robustness of the results, the Finger-Kreinin index was calculated for the French and the German regional data as well and led to very similar results.

${ }^{18}$ When calculating sectoral concentration indices of different sectors across a number of regions, regional size has to be taken into account in the same way. 
By the use of relative sectoral sizes of the industrial sectors in EU in this index, attention is paid to the difference of sectoral sizes in the EU (in a country), i.e. larger sectors do not drive the level of the concentration index due to higher levels of investment. This relative specialisation index reflects "relative investment performance"19, i.e. a ratio of $1.10(0.9)$ means that the country's (region's) investment share in the particular industrial sector is $10 \%$ higher (lower) than the sector's share in all industrial sectors in Europe (in the respective country).

In order to construct Gini-coefficients as a measure of relative regional concentration across industrial sectors which are comparable across countries or regions, these specialisation indices are weighted and aggregated ${ }^{20}$. As the number of sectors or regions included in the calculation has an influence on the coefficient's range, standardised "Lorenz-Münznercoefficients" (Cowell, 1995) can be constructed in the following way:

$\mathrm{G}_{\text {standardised }}=\mathrm{G}^{*}$ [number of sectors (regions) / number of sectors (regions) -1$]$.

These standardised and mostly used Gini-coefficients range between 0 and 1, thus directly reflecting the degree of industrial similarity. A coefficient of 0 is obtained when the distribution of relative investment shares in the country (region) is equal to the distribution of the average investment shares in the EU (the respective national country).

\section{IV.1 New empirical evidence: Allocation of direct investments and gross fixed capital formation in EU countries}

The sectoral disaggregation is determined by the 2-digit disaggregation level of the Eurostat REGIO database (described in the data appendix): 17 sectors are in general integrated in the analysis. The FDI stock data for 1995 to 1997 are rather complete and even more disaggregated than the data before 1995. Nonetheless, Gini-coefficients for 1995 to 1997 have been calculated using the same sectoral disaggregation as the REGIO database (generally including 17 subsectors) to improve the intertemporal comparability.

Kalemli-Ozcan, Sorensen and Yosha (1999) point to the fact that "many shocks may be common to several 3-digit industries; for instance, oil-shocks affecting most chemical industries". In addition, this is enforced by strong intra-industry linkages what makes the 2-digit level a relevant perspective. However, one reason for the use of further disaggregated data would be the inconsistency of the above presented results of e.g. Klüver and Rübel (1998) which found differing results at 2- and 3-digit aggregation levels. For practical reasons of comparability and regional data availability (being at the 2-digit level), we use approximately the same sectoral structure in all parts of this study.

As the economic debate about the reliability of DI data and the non-comparability of DI stock and flow data is still ongoing, it would have been useful to make results of both, DI stock and

\footnotetext{
${ }^{19}$ This specialisation index has first been introduced by Balassa for the analysis of the relative export performance of a country by use of export data and is known as the "revealed comparative advantage" index in international trade theory [see e.g. Balassa (1989:19)].

${ }^{20}$ For details on the construction of Gini-coefficients see e.g. Cowell (1995).
} 
flow data, subject to a profound comparison. However, due to technical reasons, this analysis was restricted to the use of DI stock data. DI sectoral inflows are sometimes marked by disinvestment (non-positive inflows) ${ }^{21}$. A strong advantage of DI stock data is their representation of the actual concentration of cumulated foreign capital while flow data give the latest changes in specialisation being of a high variability and underlying annual fluctuations. Although the concrete definitions of DI flows and stocks are - as agreed upon in the IMF BoP Manual - internationally harmonised, DI data often lack perfect consistency ${ }^{22}$.

\section{Allocation of national stocks of FDI inflows}

Up to 13 differentiated sectors could be included in the analysis of FDI allocation for 1995 to 1997. For the six countries considered prior to 1995, data were only available in less detail, i.e. only 9 sectors - adapted to REGIO's sectoral disaggregation - have been included in the analysis. Results for both, concentration and specialisation indices, are given in Table A2 and Table A3 in the appendix. As the sum of European DI for the different sectors has not been available prior to 1995 , relative specialisation has been constructed in relation to sectoral value added at factor costs taken from the REGIO database ${ }^{23}$. As a consequence, the specialisation indices cannot be interpreted as the region's relative DI performance with values of more than 1 representing a relatively stronger investment share in the particular sector. Though, it can be assumed that the sector's share in national gross value added approximately reflects the different sectors' relative economic importance. Thus the specialisation indices prior to 1995 can be interpreted in relation to each other.

In all six countries considered (see Table A2a), the stock of FDI inflows is most important in the chemicals industry - only in the UK, the relative specialisation in paper \& printing prod-

21 „Disinvestment is formally defined as withdrawal of DI capital. The most frequent cases are that the direct investor sells participation (e.g. shares) it had invested in the direct investment enterprise or that intercompany debt (e.g. loans) is paid back“" (Eurostat, 1998: 8).

With respect to DI stock data, negative stocks are rather sporadic - in four years in Corsica, three times in Belgian regions, ten times in German regions in 1995-98 and four times in 1992-94. In all cases, the value of negative stocks is nearly zero, and such negative values can be expected to be the result of revaluation procedures. Therefore they could be replaced by zero stocks of inflows in the calculation of the Gini-coefficients. As to be expected, this procedure leads to an increase in the respective Gini-coefficients compared to the omission of the respective sectoral stock.

${ }^{22}$ For a detailed comment on the problems of international comparable DI data see OECD (1999).

${ }^{23}$ As national or regional GFCF and FDI data are not in all cases as complete as we wish them to be, we had to use adequate but different data representing the economic extent or importance of the different sectors in any country or region to calculate specialisation indices of GFCF or FDI for these sectors in all countries or regions. Therefore it is sometimes referred to data of gross value added at factor costs when calculating the specialisation indices. Eurostat (2000b) similarly uses the regional contributions of national gross value added as distributional weights when dividing the national values of GDP among the regions.

The data on gross value added we used are given in the REGIO database for the countries considered, only in the case of Germany, we had to use adequate (and more complete) national data from the German Federal Statistical Office. In some rare cases, data have not been available for the whole time span. For the missing years, gross value added at factor costs has been approximated using data of prior or following years and GDP growth rates. In addition, data on gross value added have not been available for all 15 EU countries. However, using the available data of Belgium, Germany, France, the UK, Italy, the Netherlands, Greece, Spain, Finland as well as Sweden - altogether representing e.g. in $199289 \%$ of the aggregate GDP of the EU - we got a good approximation of the economic importance of the different industrial sectors in the EU. 
ucts is even more pronounced. Besides chemicals, Austria, and Italy are strongly specialised in transport equipment, Germany in metal products, machinery equipment \& electrical goods, the Netherlands in food, beverages \& tobacco - from the point of view of incoming international capital. Unlike expected from the brief analysis of DI patterns in chapter II, no strong relative specialisation in the services sectors can be found. Inflows in services in relation to their share in gross value added are rather low compared to the other sectors' shares - only building \& construction showing lower ratios. However, these specialisation indices ${ }^{24}$ are steadily increasing between 1985 and 1994. Unfortunately, services are only included as one aggregated sector in the analysis of DI prior to 1995.

The pattern of concentration indices between 1985 and 1994 points at a sharply decreasing sectoral concentration of FDI stocks in Germany (by $-27.7 \%$ ), the Netherlands $(-23.8 \%$ ), and Italy $(-50.9 \%)$ while concentration has increased in the UK (by $+20.5 \%)$. Its level more or less remained constant in France and Austria. Though decreasing, the on average highest sectoral concentration (see Table A2b) can still be found in the Netherlands followed by Germany. Italy and France show the lowest level of concentration.

The above found highest relative specialisation in chemicals in all countries is - with the exception of the Netherlands and Finland - not pronounced in the second half of the 1990s (see Table A3). Instead, building \& construction as well as transport \& communication services generally have received a high relative share of DI stocks followed by fuel \& power products. With respect to the other services sectors, recovery, repair, trade, lodging \& catering services have still received strong relative investments in four countries, non-market services in three, and, finally, credit \& insurance services in one country. Focusing on the same countries as in the first time period, it is solely the transport \& communications services sector in which more than two of those countries have specialised.

Like in the period prior to 1995, France, the UK and Italy prove to be less concentrated than Austria and Germany from 1995 to 1997 (see Table A2c). However, the Netherlands does not show the same extreme level of concentration as before. Even though the results are not directly comparable due to the more restricted statistics up to 1994 , it is obvious that the national levels of concentration have differed substantially less since the mid-1990s than before. In addition to those countries already included in the analysis for the first time period, four more countries could be considered for this more recent time period. Finland seems to fit well in this group of countries with respect to its level of concentration. In contrast to them, Denmark, Portugal, and Sweden show higher levels of uneven allocation of FDI.

With respect to the concentration indices, there is no evidence of general differences between intra-EU DI and world DI into EU countries in 1995-97 (see Table A2c). Instead, the pattern of relative specialisation calculated on the basis of the stock of intra-EU DI inflows more or less reflects the one on the basis of the stock of world DI inflows. In some years, concentration of intra-EU DI seems to be slightly higher, in others slightly lower than world DI into EU

\footnotetext{
${ }^{24}$ Throughout the study, detailed specialisation or concentration indices for each year are not presented in the appendix due to space restrictions.
} 
countries - but in each case, there is only a small difference in the level of concentration. Additionally, specialisation patterns are extremely similar as well.

\section{Allocation of national GFCF}

Results of the analysis of GFCF specialisation and concentration patterns on the national level are given in Table $\mathrm{A} 4{ }^{25}$. In contrast to the allocation of FDI stocks, only Belgium is marked by relatively high GFCF in chemicals. Denmark, France, and the UK are specialised in fuel \& power products, Denmark and Ireland in transport \& communication services, Belgium and Luxembourg in ferrous and non-ferrous ores and metals, Ireland and Italy in agriculture, forestry and fishery - these four seem to be the sectors with the most relative importance in investment at the national level. Besides the relative specialisation in transport \& communication services of Denmark and Ireland, services of credit and insurance institutions demonstrate one of the highest specialisation levels for Luxembourg while France shows a strong relative specialisation in other market services. This shows that a certain - though not outstanding - relative importance of services can be found on the basis of the GFCF data.

Due to the extremely varying sectoral availability in Denmark, Ireland, and Luxembourg, the comparability of the results across time is not generally assured (see cases marked in italics in Table A4b) and - exceptionally - Gini-coefficients are presented in detail and not in form of averages in the appendix. Averages, however, have to be interpreted carefully. We therefore sometimes refer to selected periods of time when discussing concentration tendencies in the following. Concentration has been increasing in Belgium (by 18.2\%), Denmark (21.6\% from 1987-94) as well as Ireland. Decreasing concentration can be found in the UK (by $8.6 \%$ from 1988-93) and in France up to 1991 - strongly increasing again in 1992. The level of sectoral agglomeration of GFCF remained rather unchanged in Luxembourg (from 1986-90) and Italy.

The two countries with the most concentrated sectoral GFCF are Luxembourg and Ireland, followed by the UK. Luxembourg takes a particular importance as financial place in the EU. Ireland is the only country being highly specialised and still subject to increasing concentration. The relative investment performance of Ireland is most pronounced in agriculture and in transport \& communication services which, probably, is in line with the above mentioned high DI in call centres and electronic commerce.

\section{Comparison of DI and GFCF concentration in EU countries}

A direct comparison of DI and GFCF concentration levels and tendencies is only possible for France, Italy, and the UK, the only countries with available data for DI and GFCF. In all three countries, the concentration of DI is stronger than the one of GFCF. However, the DI concentration is on average also higher than the GFCF concentration for the respectively available EU countries. The allocation of the steadily increasing DI inflows across different industrial sectors proves to be less uniform than the one of GFCF.

The possibility of comparing the results obtained by the use of these different capital data is rather restricted. The development of DI and GFCF concentration and specialisation seems to

\footnotetext{
${ }^{25}$ Again, sectoral sums of GFCF for EU countries were not available and the procedure described in footnote 23 was applied.
} 
be differing. In addition, no confirmation is found that DI inflows might enforce agglomeration tendencies as those sectors marked by the highest relative DI specialisation are not subject to a strong relative GFCF specialisation. Though, for both statements reliable results can only be obtained when further data will be available.

\section{Comparison of capital to production, trade and employment data}

Results of recent empirical agglomeration studies are summarised above. However, a more detailed comparison of the results of our as well as of recent studies with regard to the respective concentration level is given in the following relying on the structure of the table already presented above.

Table 2: Comparison of results on regional agglomeration

\begin{tabular}{|c|c|c|c|c|c|c|c|c|c|c|c|c|c|}
\hline Country & A & $\mathrm{B}$ & $\mathrm{D}$ & $E$ & $\mathrm{~F}$ & $G$ & $\mathrm{H}$ & I & $\mathrm{L}$ & $\mathrm{N}$ & $\mathrm{P}$ & $S$ & $\mathrm{U}$ \\
\hline $\begin{array}{l}\text { REGIO GFCF data 1985- } \\
\text { 94, own calculations }\end{array}$ & - & $\mathrm{L}$ & I & $\mathrm{H}$ & $\mathrm{L}$ & - & - & I & $\mathrm{H}$ & - & - & - & I \\
\hline $\begin{array}{l}\text { Eurostat FDI data 1985-94, } \\
\text { own calculations }\end{array}$ & I & - & - & - & I & $\mathrm{H}$ & - & I & - & $\mathrm{H}$ & - & - & I \\
\hline $\begin{array}{l}\text { REGIO employment data } \\
1985-94 \text {, own calculations }\end{array}$ & - & $\mathrm{L}$ & I & I & $\mathrm{L}$ & - & $\mathrm{H}$ & I & I & - & $\mathrm{H}$ & I & - \\
\hline $\begin{array}{l}\text { UNIDO employment data } \\
\text { 1980-90 (Amiti, 1999) }\end{array}$ & - & $\mathrm{L}$ & $\mathrm{L}$ & - & $\mathrm{L}$ & $\mathrm{L}$ & I & $\mathrm{L}$ & - & $\mathrm{L}$ & I & $\mathrm{L}$ & $\mathrm{L}$ \\
\hline $\begin{array}{ll}\text { UNIDO production data } \\
1980-90 \text { (Amiti, 1999) }\end{array}$ & - & $\mathrm{L}$ & I & - & $\mathrm{L}$ & $\mathrm{L}$ & I & $\mathrm{L}$ & - & $\mathrm{L}$ & I & $\mathrm{L}$ & $\mathrm{L}$ \\
\hline $\begin{array}{l}\text { Interindustrial trade }(\mathrm{Eu}- \\
\text { rostat data, 1980-94) } \\
\text { 1997) }\end{array}$ & - & $\begin{array}{l}\text { L- } \\
\text { I }\end{array}$ & $\mathrm{H}$ & $\mathrm{H}$ & $\begin{array}{l}\text { L- } \\
\text { I }\end{array}$ & $\begin{array}{l}\text { L- } \\
\text { I }\end{array}$ & $\mathrm{H}$ & I & $\begin{array}{l}\mathrm{L}- \\
\mathrm{I}\end{array}$ & I & $\mathrm{H}$ & I & $\begin{array}{l}\mathrm{L}- \\
\mathrm{I}\end{array}$ \\
\hline \multicolumn{14}{|c|}{ Intra-Industrial-Trade (level of diversification, not concentration): } \\
\hline $\begin{array}{l}\text { OECD Export data } 1970-85 \\
\text { (Greenaway\&Hine, } \\
\text { Michaely measure) }\end{array}$ & $\begin{array}{l}\mathrm{I}- \\
\mathrm{H}\end{array}$ & $\begin{array}{l}\mathrm{I}- \\
\mathrm{H}\end{array}$ & $\mathrm{I}$ & I & $\mathrm{H}$ & $\mathrm{H}$ & $\mathrm{L}$ & I & - & I & & $\begin{array}{l}\mathrm{I}- \\
\mathrm{H}\end{array}$ & $\mathrm{H}$ \\
\hline $\begin{array}{l}\text { OECD Im- and Export data } \\
\text { 1970-85 (Greenaway\&Hine, } \\
\text { 1991, Grubel-Lloyd index) }\end{array}$ & $\begin{array}{l}\mathrm{I}- \\
\mathrm{H}\end{array}$ & $\mathrm{H}$ & I & I & $\mathrm{H}$ & I & $\mathrm{L}$ & I & - & $\begin{array}{l}\mathrm{I}- \\
\mathrm{H}\end{array}$ & $\begin{array}{l}\mathrm{L}- \\
\mathrm{I}\end{array}$ & I & $\mathrm{H}$ \\
\hline
\end{tabular}

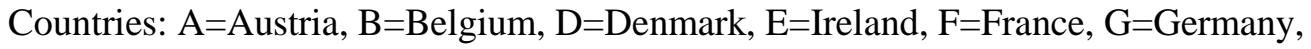
$\mathrm{H}=$ Greece, I=Italy, L=Luxembourg, N=Netherlands, $\mathrm{P}=$ Portugal, $\mathrm{S}=$ Spain, $\mathrm{U}=\mathrm{UK}$.

For definition of levels of concentration see note of Table 1.

In addition to the concentration indices of GFCF allocation, own calculations on the basis of available sectoral employment data taken from the REGIO database at the national level have been conducted ${ }^{26}$. Concentration of employment across sectors has been decreasing in Spain and Portugal in this period of time, for all other countries no specific pattern of changes can be detected on the basis of these data for 1985 to 1994. The highest (however not intermediate like in the Amiti-study) level of concentration in Portugal and Greece as well as an intermediate (low) level in Denmark (France and Belgium) is found for 1985 to 1994 largely confirm-

\footnotetext{
${ }^{26}$ Results are available from the author upon request.
} 
ing the results of Amiti (1999) for 1980 to 1990. Unlike Amiti's calculation, an intermediate (not low) concentration level is the result for Spain and Italy. Our Gini-coefficients seem to be somewhat higher. This should be due to the fact that the Gini-coefficients in our analysis are standardised ${ }^{27}$ while Amiti probably uses non-standardised Gini-coefficients.

Austria, Belgium, Italy, France, Spain, and the UK show only low or intermediate levels of concentration for all indicators. Portugal and Greece, instead, seem to be highly concentrated which is simultaneously reflected by most indicators ${ }^{28}$. The other countries are subject to differing patterns and seem to be highly concentrated with respect to some of the variables analysed: Denmark shows a high level of concentration in trade, Ireland in capital and trade, and finally Germany, the Netherlands, and Luxembourg in capital.

In all cases for which coefficients for capital and employment data could be calculated, the absolute level of concentration is higher for capital than for employment. On the national level, it can therefore be concluded that employment is more uniformly allocated than capital, possibly due to the lower mobility of employment. As long as empirical analysis only regards employment, the level of concentration found is biased towards lower concentration.

\section{IV.2 New empirical evidence: Allocation of direct investments and gross fixed capital formation in European regions}

The focus is now on regional, not national, allocation of capital. This perspective is particularly important as agglomeration tendencies might only be evident when regarding small economic entities. In addition, regions that do not have adequate regional shock absorbing mechanisms might be confronted with regional asymmetric shocks in case of differing and increasing, perhaps even cumulative, regional concentration and specialisation processes while economic policy is often established at the national or even the EU level.

Those EU countries are included in the regional analysis which report sufficiently sectorally disaggregated regional data for GFCF in the Eurostat REGIO database (described in the data appendix): Denmark, Ireland, Belgium, France, the UK as well as Luxembourg. As comparable regional data for GFCF is only available up to 1994 by end-2000, the concentration indices could only be calculated for the second half of the 1980s as well as the beginning of the 1990s. The specialisation of Denmark, Luxembourg, and Ireland, in the REGIO database being monoregional on NUTS 2-level, already appears in the analysis at the national level.

The disaggregation of EU countries into NUTS 1-, 2- and 3-regions is primarily based on political or administrative entities. Such "normative" regions are regarded in the REGIO database for practical reasons of data availability but also in accordance with the implementation

\footnotetext{
${ }^{27}$ While standardised coefficients are adjusted to a range from 0 and 1 , what makes them directly comparable independent of the number of sectors included, non-standardised coefficients range between 0 and $(n-1) / n$ where $\mathrm{n}$ is the number of sectors included.

${ }^{28}$ An exception to this is only the concentration of production as well as the one of employment according to the calculations of Amiti (1999), but not according to our own empirical calculations.
} 
of regional policies ${ }^{29}$. These regions are not grouped together on the basis of economic criteria and this is often criticised by economists as the analysis of these regions might not give us the actual degree of concentration of economic entities. On the other hand, the analysis of normative regions disaggregated according to NUTS allows us to focus on the degree of concentration of a territorial community which is enabled to implement regional policies. As the debate about how concentrated EU's regions are originates in the question about their regional shock absorbing potential and the necessity of improving regional policies, the analysis of administrative regional entities is one relevant empirical aspect.

Unfortunately, most European regions do not conduct BoP statistics at the regional level. Other data sources on regional level DI are rarely available. Only in the case of Germany, we had access to such data. However, for this country, data on regional GFCF are not sufficiently disaggregated with respect to industrial sectors. It was therefore impossible to compare results for GFCF and FDI allocation on the regional level in Germany for the period prior to 1995.

\section{German Bundesländer}

National data on regional direct investment stocks provided by the Bundesbank statistics on international capital links was used ${ }^{30}$. These German regional FDI stock data are available from 1992-98. They are disaggregated into 19 sectors in 1992-94 and into 20 (in few cases differing) sectors in 1995-98 approximately reflecting the REGIO database's sectoral disaggregation.

With respect to all German regions, results are presented in Table A5. Focusing on specialisation patterns in Table A5a, the term "high specialisation" is, in the following, used for a relative specialisation of more than 1.5, i.e. the region's investment share in this particular sector is at least 50\% higher than the sector's share in investment in all German industrial sectors. In 1992-94 (being the period of time - restrictedly - comparable to GFCF data for 1985-94), many German countries show such a high specialisation in three sectors. In addition, there are quite a number of countries being highly specialised in more than three sectors: Baden-Württemberg, Rhineland-Palatinate as well as Thuringia in six, Schleswig-Holstein in five and finally Brandenburg, Hesse, and North Rhine-Westphalia in four sectors.

With respect to the sectors, the sector most often specialised in is manufacture of other nonmetallic mineral products ( 7 of 13) followed by chemical industries ( 6 of 15), manufacture of rubber \& plastic products (5 of 13), manufacturing of machinery \& equipment n.e.c. (5 of $16)^{31}$. An outstanding relative investment performance in manufacture of other non-metallic

\footnotetext{
${ }^{29}$ Since the 1961 Brussels Conference on Regional Economies, NUTS 2 regions are generally used by EU countries for the application of regional policies [Eurostat (1999)]. In addition, the definition of so-called „functional“ or ,,analytical“ regions might differ for each variable regarded, i.e. a general specification of regional disaggregation is inappropriate.

${ }^{30}$ This statistics is conducted to augment the BoP statistics and is based on reports on stocks of German enterprises and individuals. The BoP statistics is - in contrast - based on reports of the banking sector. Since 1989 the exemption limit is $20 \%$ of shares or voting rights in an enterprise, since 1993 the additional exemption limit based on the balance sheet total of the enterprise is DM 1 million.

${ }^{31}$ Available sectoral data differs strongly, therefore the number of available regions given in brackets is varying. In addition to these most important sectors already named, respectively four countries are highly specialised in food industries, ferrous \& non-ferrous metals industries, manufacture of medical, precision \& optical in-
} 
mineral products is demonstrated by Brandenburg and Saxony-Anhalt. Focusing on the services sectors, besides insurance $\&$ pension funding mentioned above, respectively two regions are highly specialised in real estate, renting \& business activities and transport- \& communication services. In addition, Hesse, not surprisingly, is the only country with high relative concentration of FDI stocks in credit institutions as well as in other financial institutions - the banking place Frankfort is unchallenged across German regions.

No general tendency in the sectoral allocation of DI in Germany is obvious on an aggregated level in the 1990s (averages for 1992-94 and 1995-98 are presented in Table A5b). However, in a more detailed view, the East German regions are generally more concentrated than the "old" Länder regarding the sectoral allocation of the stock of DI inflows. Insofar as whole Germany is concerned, Saarland, Mecklenburg-Western Pomerania as well as Saxony show the highest concentration of DI across sectors from 1995-98. Of the Western regions, besides Saarland, also Hamburg and Bremen (all small German Bundesländer) are highly concentrated during the 1990s. However, their level of concentration is much lower than the one of any of the new Länder besides Thuringia. The lowest level of DI agglomeration is to be found in the German Bundesländer Schleswig-Holstein, Berlin, and North Rhine-Westphalia (biggest in size). These results indicate that the small size of a region might augment the concentration level. From 1995 to 1998, the yearly level of concentration has gone up in Bremen, Brandenburg, as well as (slightly) in Hesse while it has diminished in Thuringia, Bavaria, Saarland and slightly in Saxony. The rising concentration in Bremen, Hesse, and Brandenburg and its decreasing tendency in Thuringia is confirmed by the yearly results for 1992-94.

\section{French "régions"}

The results for the allocation of GFCF in French regions are presented in Table A6 for specialisation patterns and in Table A10 for concentration patterns. Table A6 shows that, in total, 12 of the 22 French NUTS 2-regions turn out to be highly specialised in agriculture and seven in food, beverages \& tobacco. Specialised in both most unequally distributed sectors are: Basse-Normandie, Bretagne, the Loire-region, Picardie, and Poitou-Charente. Regarding the most important industrial sectors, respectively five regions are highly specialised in paper \& printing products and the textiles industries while four have a high relative importance in nonmetallic minerals \& mineral products. Most regions show a high relative specialisation in two to three industrial sectors, but some French regions are more diverged with respect to their relative investment performance: Champagne-Ardenne and Haute-Normandie in four, Picardie in six industrial sectors. Though not reaching our benchmark of 1.5 , the Ille de France, covering Paris and its surroundings has its highest relative share of investment in services of credit \& insurance companies (1.36) as well as other services (1.26). Besides the Île de France, there is not a single region showing its highest relative investment performance in any services sector.

Between 1986 and 1992, the Basse-Normandie (showing an outstanding relative - as well as absolute - importance of ferrous \& non-ferrous ores \& metals) was the most concentrated re-

struments, watches \& clocks, manufacture of basic metals, and insurance \& pension funding (data on FDI in agriculture is not available). 
gion followed by the isle of Corsica with a particular relative importance of agriculture and non-market services (see the averages presented in Table A10). The less concentrated regions in this period of time with respect to GFCF allocation were "Centre" as well as Lorraine. Taking the yearly average of the standardised Gini-coefficients, an almost steady level of concentration of GFCF can be found in French regions in 1986 to 1992. Comparing regions at NUTS 1- and NUTS 2-level, those at the more aggregated level are far less concentrated than the more disaggregated ones. Three of the six most concentrated regions can be found in the North West of France and all of the highly, but less extremely concentrated regions either in the North East or the South of France. This means that the central part of France is the less concentrated part - the only exceptions being Île de France and Champagne-Ardenne with a higher degree of concentration.

\section{Italian "regioni"}

The results for GFCF in Italian regions are displayed in Table A7 for specialisation patterns and in Table A10 for concentration patterns. The sector relatively most often specialised in, i.e. the sector with the most unequally distributed GFCF, is ferrous \& non-ferrous ores \& metals (as well as "various industries"). In addition, respectively four regions are highly specialised in fuel \& power products, transport equipment as well as textiles \& clothing, leather $\&$ footwear. However, no sector is sharply outstanding and agricultural specialisation is - in contrast to the French regions - not very important. But again, most regions are highly specialised in two to three sectors, only Lombardia demonstrates a high relative investment performance in five manufacturing sectors. Non-market services (i.e. the government sector) are of second greatest importance on the isle of Sicily (11.6\% of total Sicilian investment) - like on the isle of Corsica in France (24.3\% of total Corsican investment are invested there). The isle of Sardegna instead is highly specialised in the chemicals industries as well as fuel \& power products (though, investments in non-market services also reach $10.5 \%$ of total investment). Trentino-Alto Adige, neighbouring Switzerland and Austria, is the only region highly specialised in recovery, trade, lodging and catering services.

On average, the lowest concentration is to be found in Veneto, Toscana, and Lombardia whereas the highest is prevalent in Valle d'Aosta, Basilicata, and Molise (see averages presented in Table A10). A continuous increase in concentration is evident in the yearly levels in Abruzzo, Basilicata as well as Trentino-Alto Adige, a continuous decrease in Molise. Again, NUTS 2-regions show an on average higher degree of relative concentration than NUTS 1regions - though the difference is less marked than for French regions. Very evident, instead, is the pattern of concentration with regard to the geographical location. The Southern regions are the more concentrated ones. A high concentration in Northern Italy, however, is to be found in Valle-d'Aosta. This very small Valle-d'Aosta - neighbouring France as well as Switzerland - shows its highest relative specialisation in non-market services (on average $27.5 \%$ of investments are invested here) with the maximum Italian regional index of 3.282.

\section{Belgian "provinces"}

Table A8 and Table A10 show the results for Belgian regions. Unlike the French and Italian data, the Belgian data contains a number of missing values of differing sectors, i.e. the results for Belgium are only first indications and not as reliable as the other coefficients. In addition, 
neither regional nor national sums for GFCF have been available, therefore it is referred to the value added data in the calculation of the specialisation indices as explained above ${ }^{32}$.

A strong relative regional specialisation is evident in paper \& printing products as well as in food, beverages, \& tobacco in respectively four regions. Three regions still focus investment on fuel \& power products according to this preliminary results. The region revealing the highest level of GFCF concentration across its industrial sectors, i.e. the most uneven allocation, is the region surrounding the capital Brussels, followed by Luxembourg/Belgium and Namur (see averages presented in Table A10). The less concentrated regions appear to be OostVlaanderen as well as Liège. Extremely concentrated are in general the Southern and South Western regions as well as the region of Brussels while Liège and the Northern regions show a more uniform allocation of capital. A steady increase in the yearly concentration is to be found in Antwerpen, a steady decrease in Luxembourg/Belgium. Like in France and Italy, NUTS 2-regions are on average more concentrated than NUTS 1-regions.

\section{$\underline{\text { UK regions }}$}

GFCF data for UK regions are only available at the NUTS 1-level, in addition, data for the NUTS 1-regions North, North West, and South East is missing. The average results for UK regions are given in Table A9 and Table $\mathrm{A}_{10} 0^{33}$. With respect to the relative specialisation in 1985 to $1987^{34}$, the British regions show the highest values for agriculture and food, beverages \& tobacco as well as ferrous \& non-ferrous ores \& metals, other than radioactive - however, only nine sectors could be included due to missing data. Relative regional concentration is most pronounced in Northern Ireland while GFCF is rather uniformly allocated across the industrial sectors in Yorkshire \& the Humber as well as the East Midlands. In addition, it appears to be increasing in Northern Ireland over the analysed years.

\section{IV.3 Agglomeration tendencies of capital in the EU: comparison of re- sults at national and regional level}

In 1985-94, national sectoral concentration has, with respect to FDI allocation, decreased in Germany, the Netherlands as well as in Italy, increased in the UK and remained constant in France and Austria. Regarding GFCF concentration, it has decreased in France (up to 1991) and the UK, increased in Belgium, Denmark, and Ireland while it was rather unchanged in Luxembourg (1986-90) and Italy. This increasing (decreasing) concentration in Belgium

\footnotetext{
${ }^{32}$ Following this procedure, relative specialisation indices cannot be interpreted as relative investment performance. However, their levels of specialisation can be analysed in relation to each other and be used for the calculation of Gini-coefficients.

${ }^{33}$ For this period, consistently nine sectors had been available while for the 1988-93 period only four, though consistently the same, sectors could be included.

Due to a problem of data availability, total GFCF for UK and UK regions had to be approximated for 1985-87 using its level in 1988 and the growth of manufacturing GFCF of UK and UK regions for 1985-87.

${ }^{34}$ For the period 1988 to 1993 , only four sectors could be included in the calculations. Of these sectors, GFCF in agriculture and building \& construction have been relatively more important than in transport \& communication services and fuel \& power products.
} 
(France, UK, Italy, and Germany) is not confirmed at the regional level due to the more or less unchanged (i.e. unsystematically changing) level of regional concentration. Many of the European regions show a lower level of concentration at the end of the 1980s than in the mid1980s which again is increasing in the first half of the 1990s, possibly a result of the Single Market.

When differentiating tendencies in the primary, the industrial and the services sectors, several features can be detected. Of the five EU countries with available regional data ${ }^{35}$ only Italy has been relatively specialised in agriculture, forestry \& fishery with regard to DI (1995-97) or GFCF. With respect to the regional level, more than half of the French régions and four of the eight UK regions, but only three of the 20 Italian regioni $^{36}$ show high relative sectoral importance. This signifies that agriculture is more or less evenly distributed among Italian regions (concerning the regional share in total GFCF) while the inequality of the relative distribution of GFCF in agriculture among British and French regions is very strong.

However, while all five EU countries and six of the 16 German Bundesländer from 1992-94 (though only two from 1995-98) show a high relative specialisation in chemical industries, in France only three (of 22), in Italy three (of 20) regions as well as two Belgian regions (of the nine with available data) for GFCF are marked by a high relative specialisation in chemicals $^{37}$. This demonstrates that though the chemical industry is of particular relative importance in the five EU countries, it is allocated quite uniformly (unlike agriculture) within these countries besides Germany.

Instead, specialisation in the ferrous and non-ferrous ores and metal industry is of highest relative importance in a number of regions in Italy ( 5 of 20) and UK (4 of 8). The same is true for the food industries in Belgian (4 of 11 with available sectoral data), British (4 of 8) and French (7 of 22) regions, and paper \& printing products in French (5 of 22) and Belgian regions (4 of 10 with available sectoral data), and textiles industries in French (5 of 22) and Italian regions (4 of 20) as well as, finally, for fuel \& power products and transport equipment in respectively four of 20 Italian regions, manufacture of rubber \& plastic products and of other non-metallic mineral products in respectively five and seven German regions ${ }^{38}$.

With respect to the services sectors, however, only few (4 Italian, 2 French, 10 German, no Belgian or British) regions show a high relative specialisation in some services, e.g. credit and insurance services (Île de France, Hesse and Lazio). In Belgium and the UK, this result might be due to largely missing sectoral or regional data. At the national level, too, a steadily increasing specialisation of DI as well as of GFCF in services is evident.

\footnotetext{
${ }^{35}$ Like explained above, the Belgian data is very incomplete and specialisation indices only first indications. In addition, data is not available for a number of sectors being agriculture, credit sector, non-market services, other services, transport \& communication services as well as very restricted for transport equipment and Recovery, repair, trade, lodging and catering services.

${ }^{36}$ In the German and Belgian regional data the agricultural sector is omitted.

${ }^{37}$ In the UK regional data the chemical sector is omitted.

${ }^{38}$ In addition, respectively three Belgian regions are relatively specialised in fuel \& power products, nonmetallic minerals \& mineral products, and ferrous \& non-ferrous ores and metals. However, due to the high number of missing sectoral data for Belgian regions, these results are not reliable.
} 
Economic developments in the sectors listed above will always affect a number of regions (and not only one or two) in the named countries to a particular relative extent and not all regions to a uniform extent. The absolute extent of negative disturbances, however, depends on the absolute size of the regional sector. Negative economic effects in the industrial sectors named above can be expected to be of national relevance in case of high absolute investment or a high number of regions concerned.

\section{IV.4 Patterns of regional concentration processes}

One important feature detected above in the analysis of French, Italian, and Belgian regions (the only countries with available GFCF data for NUTS 1- and NUTS 2-levels) is the higher level of concentration when regarding the more disaggregated NUTS 2-regions in comparison to the NUTS 1-regions. Further insights into the process of regional concentration might be gained from a descriptive comparison of some of the more "extreme" regions. Table A11 and Table A12 focus on the two least and the two most concentrated regions in terms of capital allocation in each country according to NUTS 2 and NUTS 1.

Considering employment concentration ${ }^{39}$, those regions that are highly concentrated in capital allocation are usually marked by a lower concentration of employment and vice versa. Of the regions highly concentrated in capital, only Basilicata of the NUTS 2-regions as well as Sardegna and Sicilia of the NUTS 1-regions are marked by higher employment concentration than capital concentration. And of the regions with a relatively uniform allocation of capital, only the Belgian NUTS 2-region Liège and the NUTS 1-region Vlaams-Gewest show a slightly lower concentration of employment than of capital. In all other cases, the descriptive analysis of these regions points at a higher degree of similarity in the level of employment concentration in contrast to sharper differences in the level of capital concentration across EU regions. In addition, the level of regional concentration in employment remains extremely stable over time in all regions considered showing only few and no systematic variation. Variation in the regional concentration of GFCF instead is higher, but shows no systematic pattern over time either.

For most regions considered, it can be stated that the unemployment rate is higher in the regions with stronger than in those with lower concentration of capital, a result which is even more pronounced with respect to the NUTS 1-regions. The share of regional employment in total national employment is consistently higher in the less concentrated regions (except for the French NUTS 1-regions Île de France and Méditerranée as well as the Belgian NUTS 2region Bruxelles-capitale). The net migration of population (in 1997 - the only available year so far), instead, shows no systematic pattern neither between nor within the two groups of regions. The number of patents is higher in those regions with more uniform capital allocation

\footnotetext{
${ }^{39}$ To ensure the comparability with the concentration indices, national employment shares were related to sectoral value added (at factor costs) shares for the calculation the specialisation indices. Employment concentration of UK regions could not be calculated due to the low number of sectors (3) for the whole time period.
} 
than in those regions with stronger capital concentration ${ }^{40}$. Bruxelles-capitale (classified as NUTS 2-region) as well as Île de France and Méditerranée again prove to have a different pattern with comparably high numbers of patents. Though capital is not allocated uniformly across all industrial sectors in these regions, they are - exceptionally - marked by an excellent economic performance. And the relatively high number of patents offers an outstanding growth potential. It has to be stressed though that the level of capital concentration of the two highest concentrated French regions is relatively low - the one of all French NUTS 1-regions being rather low and almost similar.

With respect to GDP per capita and GFCF in percent of GDP, there are no systematic differences between the regions analysed. But those regions with a higher number of patents are also marked by higher absolute GFCF as well as consequently by higher absolute GDP in addition to the in general more uniformly allocated GFCF across the industrial sectors. In this context, it has to be stressed that no causal relationship can be derived from this purely descriptive analysis. Nevertheless, higher concentrated regions seem to be performing worse in economic terms than lower concentrated regions with respect to unemployment rate, the share of regional to total employment, the number of patents, and total regional GDP as well as total regional GFCF.

\section{Conclusion}

Increasing concentration is problematic insofar as it enforces potential agglomeration tendencies which are in contrast to the neo-classical proposition of a steady-state growth and of a convergence of interregional differences in output or income. The question of adequate policy measures has to be raised if the necessity of a stronger regional shock absorbing potential is growing. The importance of economic policy at the EU level is constantly increasing. Afterall, the European integration process undisputedly has a strong influence on the potential allocation of production factors across EU regions. Liberalisation measures and the introduction of the euro accompanied by capital market integration and higher factor mobility might have been or will be further triggers of such agglomeration processes.

Given this economic context, this paper aims to illustrate agglomeration tendencies. The above found results show a strong uneven allocation of capital in Ireland, Germany, the Netherlands, and Luxembourg. In addition, Greece and Portugal (for which adequate capital data have not been available) prove to be highly concentrated regarding a number of different indicators. With respect to specialisation and concentration indices for DI in 1995-97, there is no evidence of generally differing patterns between intra-EU and World DI stocks in EU countries. European integration thus does not seem to have had a particular intra-European effect on factor allocation. The new focus on capital, however, empirically turns out to be especially important as employment is found to be on average allocated more uniformly than capital which is particularly evident at the national level. Differences in the regional levels of concentration are less sharp for employment than for capital. In addition, the level of employment

\footnotetext{
${ }^{40}$ In all regions considered, the variation of the number of patents is not very high over time.
} 
concentration is either constant or decreasing (Portugal and Spain) while increasing levels of capital concentration are evident in Ireland (for GFCF) and the UK (for FDI). These results support the hypothesis that due to its higher mobility capital might substitute for employment and catch concentration processes inside the EU to a larger extent.

In addition, the regionally disaggregated focus turns out to be very important as the level of concentration is consistently higher in NUTS 2- than in NUTS 1-regions in the three countries with available data for both regional aggregation levels. Agriculture has been found to be more or less equally distributed across Italian regions. But there is a strong unequal relative distribution of GFCF across British and French regions. Though the chemical industry is of particular relative importance (at the national level) in all five EU countries with available regional data, it is allocated quite uniformly within these countries with the exception of Germany. A certain - though not strong - relative importance of services sectors can be found which is particularly strong only in Ireland and Denmark in transport \& communications services and in some German regions for different services. However, in most countries or regions specialisation indices for services are steadily increasing between 1985-94. As the importance of services has constantly been increasing inside the EU in the 1990s, further agglomeration effects are to be expected due to the ongoing market liberalisation in financial markets, telecommunications etc. In addition, many regions show an increasing capital concentration in the beginning of the 1990s, the time of the inauguration of the Single Market, which might also be a sign of further increasing concentration.

In a descriptive analysis highly concentrated regions could be found to be of a poorer economic performance than lower concentrated regions with respect to unemployment rate, number of patents, total regional GDP and total regional GFCF. Causal relationships, though, remain to be detected in further econometric analyses.

However, these higher concentrated regions are to be found in the peripheral areas of the respective countries like e.g. in Eastern Germany and Southern Italy. In some countries, some central regions are also marked by a high level of concentration - though the specialisation of these regions is often particularly strong in the fast growing services sectors (like Île de France, Hesse) and seems not to give reason for further policy concerns. The situation in the (highly concentrated and worse performing) peripheral regions, though, stresses the importance for the EU and the EU member countries not to neglect their focus on the economic development of peripheral regions. 


\section{References}

AмIтI, M. (1999): Specialization Patterns in Europe, Weltwirtschaftliches Archiv 135 (4), 573-593.

BAJo-Rubio O. AND S. Sosvilla-Rivero (1994): An Econometric Analysis of Foreign Direct Investment in Spain, 1964-89, Southern Economic Journal 61 (1), 104-120

BALASSA, B. (1989): Comparative advantage, trade policy and economic development, Hasvester Wheatsheaf, Hestfordshire, 18-79.

Brenton P, F. DiMAURo AND M. LÜCKE (1998): Economic Integration and FDI: An Empirical Analysis of Forgein Investment in the EU and in Central and Eastern Europe, Kiel Working Paper No. 890, Kiel.

BRÜLHART, M. (1998): Trading Places: Industrial Specialisation in the European Union, Journal of Common Market Studies 36 (3), 319-346.

CAVES, R. E. (1996): Multinational enterprise and economic analysis, Second edition, Cambridge.

Cowell, F. A. (1995): Measuring Inequality, London, Prentice Hall.

European Commission (1997): Trade Patterns inside the Single Market, The Single Market Review - Impact on Trade and Investment, Subseries IV (2):.

EUROPEAN COMMISSION (1998a): Trade, labour and capital flows: the less developed regions, The Single Market Review - Aggregate and regional impact, Subseries VI (3).

EUROPEAN COMMISSION (1998b): Foreign direct investment, The Single Market Review - Impact on trade and investment, Subseries IV (1).

EuRoPeAn COMMISSION (2000): Finanical Services Priorities and Progress, Third Report, $\operatorname{COM}(2000)$ 692/2 final, Brüssel.

EUROSTAT (1998): European Union direct investment Yearbook 1998, Luxembourg.

EuROSTAT (1999): Statistik kurzgefaßt, Allgemeine Statistik 1-3/1999, Luxembourg.

Eurostat (2000a): REGIO database - User's guide, European Communities, Luxembourg.

Eurostat (2000b): Regions: Statistical yearbook 2000, Luxembourg.

GreEnAwAY, D. AND R.C. Hine (1991): Intra-industry Specialization, Trade Expansion and Adjustment in the European Economic Space, Journal of Common Market Studies 29(6), 389403.

GÜßEFELDT, J. AND C. STREIT (2000): Disparitäten regionalwirtschaftlicher Entwicklung in der EU, Center for Globalization and Europeanization of the Economy Discussionpaper 5, Göttingen.

HAALAND, J.I., H.J. KIND, K.H.M. KNARVIK AND J. TORSTENSSON (1999): What determines the economic geography of Europe?, Centre for Economic Policy Research, Discussion Paper No. 2027, London. 
Kalemli-OzCAn S., B.E. Sorensen And O. Yosha (1999): Risk Sharing and Industrial Specialization: Regional and International Evidence, mimeo.

KIM, S. (1995): Expansion of markets and the geographic distribution of economic activities: the trends in the U.S. regional manufacturing structure, 1860 - 1987, Quarterly Journal of Economics, 881-908.

KLÜVER, A. AND G. RÜBEL (1998): Räumliche Industriekonzentration und die komparativen Vorteile von Ländern - eine empirische Studie der Europäischen Union, Passauer Diskussionspapiere, Diskussionsbeitrag No. 5-98, Passau.

KRIEGER-Boden, C. (1999): Nationale und regionale Spezialisierungsmuster im europäischen Integrationsprozeß, Die Weltwirtschaft (2), 234-254.

KrugMan, P. (1991): Geography and Trade, Cambridge/Massachusetts.

Krugman, P. (1998): What's New about the New Economic Geography?, Oxford Review of Economic Policy 14 (2), 7-17.

OECD (1999): Report on the Survey of Implementation of Methodological Standards for Direct Investment, DAFFE/IME (99) 14, Paris.

OECD (2000): Recent Trends in Foreign Direct Investment, Financial Market Trends 76 (July), 23-41.

SAPIR, A. (1996): The Effects of Europe's Internal Market Program on Production and Trade: A First Assessment, Weltwirtschaftliches Archiv 132 (3), 457-475.

United Nations (1992): The Determinants of Foreign Direct Investment - A Survey of Evidence, New York.

United NATIONS (1999): World Investment Report 1999 - Foreign Direct Investment and the Challenge of Development, New York. 


\section{Appendix}

\section{Variable list}

AGRO Agricultural, forestry and fishery products

BUIL Building and construction

CHEM Chemical products

CHIN Chemicals \& chemical products

CRED Services of credit and insurance institutions

CRIN Credit institutions

ELEC Electrical machinery \& apparatus n.e.c.

FINA Other financial institutions

FOOD Food, beverages, tobacco

FUEL Fuel and power products

INSU Insurance \& pension funding, except compulsory social security

IRST Iron \& steel industry

MACH Machinery \& equipment n.e.c.

MANP Manufactured products

MEOP Medical, precision \& optical instruments, watches \& clocks

META Ferrous and non-ferrous ores and metals, other than radioactive

METP Metal products, machinery equipment, electrical goods

MINE Non-metallic minerals and mineral product

MIQU Mining \& quarrying

MOTO Motor vehicles, trailers \& semitrailers

NRME Non-ferrous metals industry

NMSE Non-market services

OFCO Office machinery \& computers

OTHS Other market services

PAPE Paper and printing products

RUPL Rubber and plastic products

SERV Market services

TEXT Textiles and clothing, leather and footwear

TRAD Trade

TRCO Transport and communication services

TREQ Transport equipment

TRLO Recovery, repair, trade, lodging and catering services

VARI Products of various industries 


\section{Data appendix}

\section{Eurostat FDI stock data}

The FDI stock data from the Eurostat Direct Investment Yearbook (like the OECD FDI data) is disaggregated in different sectors based on ISIC Rev.3 and NACE Rev.1. Data for 1995 to 1997 are taken from ISY CD 2000 while the data before 1995 are taken from ISY CD 1999.

\section{Eurostat Regio database}

By use of the Nomenclature of Territorial Units for Statistics (NUTS - Nomenclature des unités territoriales statistiques), the REGIO database disaggregates data for the three aggregation levels NUTS 1, 2 and 3. However, data for GFCF is only available at the NUTS 2-level. The UK as well as Germany (and here regional data is only given for West German regions) do not provide data disaggregated further than NUTS 1-level. Luxembourg, Denmark as well as Ireland are only regarded as one single region on the NUTS 1- as well as on the NUTS 2level (=monoregional countries).

Table A1: Regional data for GFCF from the REGIO database

\begin{tabular}{|l|l|l|l|l|}
\hline Country & $\begin{array}{l}\text { NUTS } \\
\text { level }\end{array}$ & $\begin{array}{l}\text { Respective national } \\
\text { disaggregation level }\end{array}$ & $\begin{array}{l}\text { Number of } \\
\text { regions } \\
\text { NUTS 1 }\end{array}$ & $\begin{array}{l}\text { Number of } \\
\text { regions } \\
\text { NUTS 2 }\end{array}$ \\
\hline Germany & 1 & Länder & 11 & n.a. \\
\hline UK & 1 & $\begin{array}{l}\text { Groups of Counties or } \\
\text { local authority regions }\end{array}$ & 11 & n.a. \\
\hline Belgium & 2 & Provinces & 3 & 11 \\
\hline France & 2 & Régions & 8 & 22 \\
\hline The Netherlands & 2 & Provincies & 4 & 12 \\
\hline Italy & 2 & Regioni & 11 & 20 \\
\hline Denmark & $1 \& 2$ & - & 1 & 1 \\
\hline Ireland & $1 \& 2$ & - & 1 & 1 \\
\hline Luxembourg & $1 \& 2$ & - & 1 & 1 \\
\hline
\end{tabular}

Note: Version of NUTS 1995.

From 1991 onwards, Germany means „Germany after reunification“; for population this is valid from 1990 onwards.

French oversea departments (DOM - départements outre-mer) are not counted in total sums for France as well as for the EU. 
Table A2: Specialisation and concentration patterns of DI stocks of inflows in EU-Countries

a) Specialisation patterns for DI stocks of inflows, 1985 to 1994

\begin{tabular}{|l|c|c|c|c|c|c|c|c|c|c|}
\hline Specialisation indices & FOOD & TEXT & PAPE & CHEM & MINE & METP & TREQ & BUIL & SERV & average \\
\hline \hline Austria & 0.632 & 1.482 & 1.152 & 4.337 & 0.652 & 2.375 & 3.274 & 0.506 & 0.692 & $\mathbf{1 . 6 7 8}$ \\
\hline France & 1.658 & 0.689 & 1.506 & 3.153 & 1.940 & 1.665 & 1.409 & 0.062 & 0.962 & $\mathbf{1 . 4 4 9}$ \\
\hline Germany & 1.213 & 0.338 & 0.606 & 4.410 & 1.698 & 2.039 & 1.650 & 0.057 & 0.919 & $\mathbf{1 . 4 3 7}$ \\
\hline Italy & 1.379 & 1.150 & 0.000 & 3.961 & 0.000 & 1.986 & 2.306 & 0.000 & 0.839 & $\mathbf{1 . 9 3 7}$ \\
\hline Netherlands & 2.658 & 0.683 & 1.792 & 9.224 & 1.304 & 1.162 & 0.425 & 0.148 & 0.774 & $\mathbf{2 . 0 1 9}$ \\
\hline UK & 1.640 & 0.203 & 3.322 & 1.725 & 0.746 & 1.415 & 1.340 & 0.091 & 0.653 & $\mathbf{1 . 2 3 7}$ \\
\hline average per sector & $\mathbf{1 . 5 3 0}$ & $\mathbf{0 . 7 5 8}$ & $\mathbf{1 . 6 7 5}$ & $\mathbf{4 . 4 6 9}$ & $\mathbf{1 . 2 6 8}$ & $\mathbf{1 . 7 7 4}$ & $\mathbf{1 . 7 3 4}$ & $\mathbf{0 . 1 7 3}$ & $\mathbf{0 . 8 0 7}$ & \\
\hline
\end{tabular}

Note: Indices are averages for 1985-94. The two most important sectors are marked for each country - specialisation index represents the region's direct investment share in the respective sector in relation to the sector's share in national gross value added.

b) Concentration of FDI stocks of inflows, 1985 to 1994

(Standard. Gini-coefficients, 9 sectors included)

\begin{tabular}{|l|c|}
\hline Concentration indices & average \\
\hline \hline Austria & 0.457 \\
\hline France & 0.362 \\
\hline Germany & 0.503 \\
\hline Italy & 0.346 \\
\hline Netherlands & 0.701 \\
\hline UK & 0.427 \\
\hline
\end{tabular}

c) Concentration of world as well as intra-EU DI stocks 1995

to 1997 (Standard. Gini-coefficients, 13 sectors included)

\begin{tabular}{|l|c|c|}
\hline Average concentration indices & World & EU \\
\hline \hline Austria & 0.371 & 0.409 \\
\hline Denmark & 0.563 & 0.567 \\
\hline Finland & 0.389 & 0.432 \\
\hline France & 0.252 & 0.248 \\
\hline Germany & 0.375 & 0.365 \\
\hline Italy & 0.273 & n.a. \\
\hline Netherlands & 0.294 & 0.296 \\
\hline Portugal & 0.467 & 0.477 \\
\hline Sweden & 0.539 & n.a. \\
\hline UK & 0.308 & 0.378 \\
\hline
\end{tabular}


Table A3: Specialisation patterns for stocks of world and intra-EU DI inflows in EU countries, averages for 1995 to 1997

\begin{tabular}{|c|c|c|c|c|c|c|c|c|c|c|c|c|c|c|}
\hline World & AGRO & FOOD & TEXT & PAPE & CHEM & METP & TREQ & FUEL & BUIL & TRLO & TRCO & CRED & NMSE & average \\
\hline Austria & n.a. & 0.406 & 1.919 & 1.403 & 1.169 & 0.742 & 1.133 & 0.128 & 2.037 & 1.774 & 1.609 & 0.877 & 0.141 & 1.112 \\
\hline Denmark & n.a. & 0.891 & 0.086 & 1.179 & 0.443 & 0.713 & 0.139 & 0.794 & 1.896 & 2.459 & 4.999 & 0.695 & 0.123 & 1.201 \\
\hline Finland & n.a. & 0.802 & 0.741 & 0.878 & 1.937 & 1.817 & n.a. & n.a. & 2.143 & 1.878 & 2.481 & 0.357 & 0.260 & 1.329 \\
\hline France & 1.222 & 1.674 & 1.334 & 0.964 & 1.337 & 0.926 & 1.387 & 0.682 & 0.310 & 0.765 & 0.768 & 0.987 & 1.896 & 1.096 \\
\hline Germany & 0.822 & 0.292 & 0.627 & 0.077 & 0.695 & 0.580 & 0.868 & 0.142 & 0.525 & 0.987 & 0.388 & 0.341 & 0.170 & 0.501 \\
\hline Italy & 2.735 & 1.151 & 2.888 & n.a. & n.a. & n.a. & n.a. & 1.770 & n.a. & n.a. & 1.611 & 2.033 & 5.196 & 2.483 \\
\hline \begin{tabular}{|l|} 
Netherlands \\
\end{tabular} & 0.771 & 1.409 & 0.552 & 1.618 & 2.015 & 0.913 & 1.034 & 0.233 & 1.863 & 1.277 & 1.649 & 1.151 & 0.775 & 1.174 \\
\hline Portugal & 1.848 & 1.045 & 3.136 & 1.694 & 0.532 & 0.580 & 0.014 & 2.329 & 4.124 & 1.257 & 0.798 & 0.912 & 0.267 & 1.426 \\
\hline Sweden & n.a. & 1.213 & n.a. & n.a. & 1.411 & n.a. & n.a. & 3.156 & 4.798 & n.a. & n.a. & 0.047 & n.a. & 2.125 \\
\hline UK & 0.411 & 0.962 & 0.540 & 1.560 & 0.539 & 1.229 & 0.529 & 2.131 & 1.071 & 1.032 & 0.634 & 1.154 & 1.739 & 1.041 \\
\hline average per sector & 1.301 & 0.984 & $\overline{1.314}$ & 1.172 & 1.120 & 0.938 & 0.729 & 1.263 & 2.085 & 1.429 & 1.660 & 0.855 & 1.174 & \\
\hline number of countries & 2 & 4 & 3 & 3 & 2 & 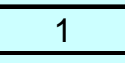 & 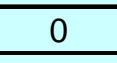 & 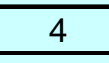 & 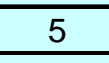 & 7 & 5 & 4 & 2 & \\
\hline$\overline{E \mathbf{E U}}$ & AGRO & FOOD & $\overline{\text { TEXT }}$ & PAPE & CHEM & "METP & $\begin{array}{l}\text { TREQ } \\
\end{array}$ & FUEL & BUIL & $\overline{\text { TRLO }}$ & TRCO & "CRED & NMSE & average \\
\hline Denmark & n.a. & 0.941 & n.a. & 1.548 & 0.465 & 0.622 & 0.178 & 0.960 & 2.135 & 2.287 & 6.386 & 0.801 & 0.140 & 1.497 \\
\hline Finland & n.a. & 0.929 & 1.114 & 0.886 & 2.108 & 2.417 & n.a. & n.a. & 2.662 & n.a. & 2.965 & 0.430 & 0.140 & 1.517 \\
\hline France & 0.949 & 1.606 & 1.377 & 1.086 & 1.389 & 0.852 & 1.598 & 1.086 & 0.371 & 0.749 & 0.748 & 1.048 & 1.475 & 1.103 \\
\hline Germany & 1.025 & 0.266 & 0.876 & 0.080 & 0.777 & 0.576 & 0.536 & 0.200 & 0.670 & 0.880 & 0.329 & 0.338 & 0.158 & 0.516 \\
\hline Netherlands & 0.800 & 0.939 & 0.817 & 2.249 & 1.548 & 0.970 & 1.349 & 0.229 & 1.868 & 1.204 & 1.700 & 1.481 & 0.490 & 1.203 \\
\hline Portugal & 1.861 & 1.050 & 3.983 & 1.893 & 0.612 & 0.631 & 0.065 & 2.971 & 4.495 & 1.309 & 0.618 & 0.923 & 0.206 & 1.586 \\
\hline UK & 0.275 & 1.155 & 0.451 & 1.195 & 0.444 & 1.314 & 0.325 & 2.092 & 0.675 & 1.304 & 0.297 & 0.908 & 1.754 & 0.938 \\
\hline average per sector & 0.982 & 0.984 & 1.436 & 1.277 & 1.049 & 1.054 & 0.675 & 1.256 & 1.839 & 1.289 & 1.863 & 0.847 & 0.623 & \\
\hline number of countries & 2 & 4 & 1 & 3 & 2 & 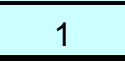 & 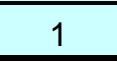 & 2 & 4 & 2 & 3 & 0 & 7 & \\
\hline
\end{tabular}

Note: Box is shaded when index reaches at least 1.5; box is in italics and bold type when sector turns out to be one of the most important in the respective region even though index does not reach 1.5. 
Table A4: Allocation of GFCF in EU countries (Lorenz-Münzner-coefficients/17 sectors)

\section{a) Specialisation indices}

\begin{tabular}{|c|c|c|c|c|c|c|c|c|c|c|c|c|c|c|c|c|c|}
\hline & AGRO & BUIL & CHEM & CRED & FOOD & FUEL & META & METP & MINE & NMSE & OTHS & PAPE & TEXT & TRCO & TREQ & TRLO & VARI \\
\hline Belgium & n.a. & 0.061 & 0.320 & n.a. & 0.203 & 0.269 & 0.300 & 0.076 & 0.246 & n.a. & n.a. & 0.205 & 0.164 & n.a. & 0.151 & n.a. & 0.256 \\
\hline Denmark & 0.339 & 0.094 & n.a. & 0.087 & 0.197 & 0.408 & n.a. & n.a. & 0.229 & 0.156 & n.a. & 0.226 & 0.074 & 0.476 & n.a. & n.a. & n.a. \\
\hline France & 0.205 & 0.084 & 0.109 & 0.091 & 0.170 & 0.292 & 0.188 & 0.115 & 0.137 & 0.206 & 0.504 & 0.144 & 0.079 & 0.263 & 0.178 & 0.121 & 0.196 \\
\hline Ireland & 0.595 & 0.063 & 0.171 & 0.183 & 0.278 & 0.238 & 0.044 & 0.118 & 0.201 & 0.080 & n.a. & 0.110 & 0.090 & 0.372 & 0.022 & n.a. & 0.153 \\
\hline Italy & 0.435 & 0.094 & 0.122 & 0.064 & 0.129 & 0.340 & 0.200 & 0.131 & 0.645 & 0.110 & 0.392 & 0.135 & 0.262 & 0.343 & 0.143 & 0.119 & 0.250 \\
\hline Luxembourg & 0.209 & 0.078 & 0.036 & 0.680 & 0.106 & 0.184 & 0.949 & 0.083 & 0.251 & 0.305 & 0.294 & 0.072 & 0.326 & 0.341 & 0.009 & 0.162 & 0.513 \\
\hline UK & 0.086 & 0.670 & n.a. & n.a. & 0.119 & 0.516 & 0.186 & 0.082 & n.a. & n.a. & n.a. & 0.204 & n.a. & 0.229 & 0.102 & n.a. & 0.130 \\
\hline average per sector & 0.312 & 0.164 & 0.152 & 0.221 & 0.172 & 0.321 & 0.311 & 0.101 & 0.285 & 0.171 & 0.397 & 0.157 & 0.166 & 0.337 & 0.101 & 0.134 & 0.250 \\
\hline
\end{tabular}

Note: Indices are averages for 1985-94. The two most important sectors are marked for each country - the specialisation index represents the region's investment share in the respective sector in relation to the sector's share in national gross value added.

\section{b) Concentration indices}

\begin{tabular}{|c|c|c|c|c|c|c|c|c|c|c|c|c|}
\hline & 1985 & 1986 & 1987 & 1988 & 1989 & 1990 & 1991 & 1992 & 1993 & 1994 & average & period \\
\hline Belgium & 0.244 & 0.199 & 0.234 & 0.238 & 0.266 & 0.294 & 0.268 & 0.275 & 0.314 & 0.288 & 0.262 & $85-94$ \\
\hline Denmark & n.a. & 0.340 & 0.316 & 0.355 & 0.402 & 0.435 & n.a. & 0.418 & 0.388 & 0.385 & 0.386 & $87-94$ \\
\hline France & 0.313 & 0.309 & 0.293 & 0.276 & 0.281 & 0.279 & 0.273 & 0.323 & n.a. & n.a. & 0.293 & 85-92 \\
\hline Italy & 0.323 & 0.331 & 0.314 & 0.316 & 0.305 & 0.302 & 0.302 & 0.313 & 0.334 & 0.332 & 0.317 & 85-94 \\
\hline Luxembourg & n.a. & 0.537 & 0.557 & 0.497 & 0.481 & 0.532 & n.a. & 0.284 & 0.281 & 0.285 & 0.521 & $86-90$ \\
\hline UK & 0.295 & 0.333 & 0.334 & 0.475 & 0.456 & 0.436 & 0.451 & 0.462 & 0.434 & n.a. & 0.452 & $88-93$ \\
\hline
\end{tabular}

Note: Intertemporal comparability is not assured in those cases marked in italics, averages are to be interpreted very carefully. Less than 17 sectors are included in Belgium (11 sectors), Denmark (4 sectors), Ireland (4 to 8 sectors), Luxembourg since 1992 (5 sectors) and finally UK (4 to 9 sectors). 
Table A5: Allocation of DI in German Bundesländer

a) Specialisation patterns for 1992 to 1994

\begin{tabular}{|c|c|c|c|c|c|c|c|c|c|c|c|c|c|c|c|c|c|c|c|}
\hline & FOOD & PAPE & MIQU & CHIN & \begin{tabular}{|l|} 
RUPL \\
\end{tabular} & MINE & IRST & NRME & MACH & ELEC & MEOP & МОТО & OFCO & TRAD & TRCO & CRIN & FINA & INSU & THS \\
\hline Baden & 0.931 & 1.258 & n.a. & 1.214 & 2.248 & 0.737 & 0.375 & 1.790 & 2.118 & 1.760 & 3.297 & 0.913 & 6.350 & 0.663 & 0.355 & 0.190 & 1.445 & 0.018 & 0.998 \\
\hline Berlin & 479 & a. & n.a. & 1.590 & 0.202 & 982 & a. & n.a. & 1.928 & 0.727 & 0.970 & n.a. & n.a. & 0.956 & 082 & .a. & .a. & 303 & 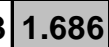 \\
\hline Bra & 33 & a. & n.a. & 2.080 & n.a. & 343 & 092 & a. & 0.192 & 0.758 & 90 & n.a. & n.a. & 0.136 & n.a. & a. & a. & a. & .912 \\
\hline & 697 & n.a. & n.a. & .490 & n.a. & & & n.a. & 0.485 & 0.225 & 0.341 & n.a. & n.a. & 1.030 & 251 & n.a. & a. & 795 & \begin{tabular}{|l|l} 
\\
\end{tabular} \\
\hline Bav & 563 & 0.565 & n.a. & 0.802 & 0.643 & 746 & 0.078 & 0.140 & 1.397 & 1.869 & 0.764 & 0.272 & $\mid 0.744$ & 1.239 & 0.659 & 0.279 & \begin{tabular}{|l|}
1.040 \\
\end{tabular} & 723 & 0.811 \\
\hline Sax & 893 & a. & n.a. & 1.193 & 0.837 & 1.661 & 0.240 & n.a. & 3.308 & 0.655 & 0.750 & 0.574 & n.a. & 0.394 & 0.115 & n.a. & n.a. & १.a. & 0.534 \\
\hline Han & 759 & n.a. & \begin{tabular}{|l|}
9.474 \\
\end{tabular} & 0.206 & 0.304 & a. & a. & 1.625 & 0.252 & 1.026 & 0.028 & n.a. & n.a. & 1.130 & 1.479 & 0.957 & 0.255 & \begin{tabular}{|l|l}
5.234 \\
\end{tabular} & 0.558 \\
\hline $\mathrm{Hes}$ & 05 & a. & n.a. & 1.556 & 0.611 & 30 & 045 & a. & 0.539 & 0.846 & 0.599 & 1.727 & 0.363 & 0.847 & 961 & 2.766 & 2.751 & 135 & 0.895 \\
\hline $\mathrm{Mec}$ & 35 & n.a. & n.a. & n.a. & n.a. & 68 & & n.a. & 0.232 & ר.a. & a. & a. & n.a. & 0.932 & 115 & n.a. & a. & a. & 0.088 \\
\hline Lou & 0.888 & 5.308 & n.a. & 0.842 & 2.362 & 0.938 & 0.407 & 6.535 & 0.778 & 1.157 & 1.165 & 0.241 & n.a. & 1.218 & 0.097 & n.a. & i.a. & 1.003 & 0.982 \\
\hline Nort & 0.894 & 1.613 & 0.215 & 0.794 & 0.792 & 1.633 & 0.694 & 0.399 & 0.841 & 0.663 & 0.588 & 1.512 & 0.113 & 1.235 & 1.592 & 0.713 & 0.246 & 0.581 & 1.343 \\
\hline Rhin & 784 & a. & n.a. & 0.406 & 2.557 & 3.246 & a. & \begin{tabular}{|l|}
6.427 \\
\end{tabular} & 1.660 & 0.531 & 2.243 & n.a. & n.a. & 0.736 & 0.744 & 0.074 & 0.000 & a. & 1.532 \\
\hline Saa & \begin{tabular}{|l|}
0.037 \\
\end{tabular} & n.a. & n.a. & 0.222 & 2.649 & a. & 39.292 & a. & 0.178 & 0.137 & \begin{tabular}{|l|}
0.492 \\
\end{tabular} & n.a. & n.a. & 0.660 & 0.132 & 1.081 & i.a. & 1.835 & 0.320 \\
\hline & n.a. & n.a. & n.a. & 1.754 & 0.209 & 13.224 & 0.839 & n.a. & 0.575 & n.a. & n.a. & n.a. & n.a. & 0.506 & n.a. & n.a. & a. & n.a. & 0.353 \\
\hline Schl & 0.000 & n.a. & n.a. & 2.077 & 1.402 & 717 & 2.031 & n.a. & 2.482 & 0.739 & 2.306 & n.a. & n.a. & 1.458 & 1.263 & a. & a. & 1.a. & 0.654 \\
\hline Thuringia & n.a. & n.a. & n.a. & 3.607 & 1.660 & 1.565 & 5.523 & n.a. & 0.875 & 0.470 & 2.844 & 3.398 & n.a. & 0.298 & 0.000 & n.a. & n.a. & n.a. & 0.000 \\
\hline av & .557 & 2.186 & 4.845 & 1.256 & 1.267 & 3.284 & 4.965 & 2.819 & 1.115 & 0.826 & \begin{tabular}{|l|l|}
1.198 \\
\end{tabular} & 1.234 & 1.892 & 0.840 & 0.846 & 0.866 & 0.956 & 1.403 & 0.795 \\
\hline num & 4 & 2 & 1 & 6 & 5 & & & & & & & & & & & & & & \\
\hline
\end{tabular}

Note: Indices are averages for 1992-94. Box is shaded when the index reaches at least 1.5.

b) Concentration indices (averages)

\begin{tabular}{|c|c|c|c|c|c|c|c|c|c|c|c|}
\hline & $92-94$ & $95-98$ & & $92-94$ & $95-98$ & & $92-94$ & $95-98$ & & $92-94$ & $95-98$ \\
\hline Baden-Württemberg & 0.47 & 0.431 & Bremen & 0.597 & 0.606 & Mecklenb.-West. Pomerania & 0.648 & 0.878 & Saxony-Anhalt & 0.812 & 0.736 \\
\hline Bavaria & 0.431 & 0.447 & Hamburg & 0.57 & 0.584 & North Rhine- Westphalia & 0.277 & 0.296 & Saxony & 0.551 & 0.797 \\
\hline Berlin & 0.359 & 0.389 & Hesse & 0.381 & 0.451 & Rhineland-Palatinate & 0.54 & 0.475 & Schleswig-Holstein & 0.262 & 0.399 \\
\hline Brandenburg & 0.687 & 0.732 & Lower Saxony & 0.526 & 0.444 & Saarland & 0.865 & 0.784 & Thuringia & 0.554 & 0.493 \\
\hline
\end{tabular}


Table A6: Specialisation indices for GFCF in French regions

\begin{tabular}{|c|c|c|c|c|c|c|c|c|c|c|c|c|c|c|c|c|c|c|}
\hline & & $\mathrm{BRO}$ & BUIL & HEM & RED & $\overline{O O D}$ & UEL & IETA & IETP & MINE & $\overline{\mathrm{MSE}}$ & THHS & PAPE & TEXT & TRCO & REQ & RLO & ARI \\
\hline \multirow{22}{*}{$\begin{array}{l}\mathbf{N} \\
\mathbf{U} \\
\mathbf{T} \\
\mathbf{S}\end{array}$} & Alsace & 0.597 & 0.950 & 1.420 & 0.815 & $\overline{1.662}$ & 0.495 & 0.633 & $\overline{1.346}$ & (1.626 & 0.837 & 1.085 & (1.685 & (1.919 & 0.770 & (1.129 & 0.905 & 1.207 \\
\hline & Aquitaine & 2.108 & 1.162 & 1.181 & 0.910 & 0.966 & 1.183 & 0.063 & 0.667 & 0.943 & 1.237 & 0.857 & 1.076 & 0.424 & 1.024 & 0.728 & 1.095 & 1.091 \\
\hline & Auvergne & 2.053 & 1.146 & 0.737 & 0.950 & 1.390 & 0.636 & 0.637 & 0.933 & 1.106 & 1.332 & 0.832 & 0.760 & 0.864 & 0.824 & 0.432 & 0.916 & 4.272 \\
\hline & Basse-Normandie & 1.687 & 0.920 & 0.327 & 0.616 & 1.602 & 0.476 & 16.875 & 1.063 & 0.699 & 0.941 & 0.644 & 0.853 & 0.463 & 0.686 & 1.615 & 0.931 & 0.903 \\
\hline & Bourgogne & 2.346 & 1.225 & 0.922 & 0.884 & 1.134 & 0.625 & 1.110 & 1.368 & 1.634 & 1.053 & 0.849 & 0.752 & 0.894 & 1.005 & 0.686 & & 1.845 \\
\hline & Bretagne & 2.445 & 1.085 & 0.249 & 0.896 & 2.358 & 0.530 & 0.048 & 0.615 & 0.863 & 1.150 & 0.963 & 0.577 & 0.295 & 0.790 & 1.352 & 1.047 & 0.967 \\
\hline & Champagne-Ardenne & & 0.887 & 0.370 & 0.781 & 2.456 & 1.126 & 0.444 & 1.556 & 1.532 & 0.935 & 0.806 & 0.696 & 1.962 & 0.919 & 0.430 & 0.848 & .478 \\
\hline & Corse & 2.156 & 1.350 & & 0.810 & 0.289 & 0.867 & & 0.141 & 0.917 & 1.680 & 0.942 & 0.127 & 0.038 & 1.223 & 0.090 & 1.310 & 0.251 \\
\hline & Centre (F) & 1.778 & 1.137 & 1.061 & 0.957 & 0.950 & 1.623 & 0.124 & 1.384 & 1.067 & 1.025 & 0.872 & 1.164 & 0.633 & 0.864 & 0.884 & 0.940 & 1.413 \\
\hline & France-Comtée & 1.083 & 1.122 & 1.144 & 0.679 & 0.898 & 0.402 & 0.281 & 1.848 & 1.057 & 1.075 & 0.874 & 0.465 & 0.619 & 0.771 & 4.307 & 0.851 & 2.345 \\
\hline & Haute & 0.919 & 0.917 & 3.772 & 0.676 & 0.908 & 1.651 & 0.267 & 1.274 & 0.944 & 0.936 & 0.696 & 3.059 & 0.768 & 1.459 & 1.653 & 0.774 & 1.226 \\
\hline & Ile de Fran & 0.084 & 0.809 & 0.799 & 1.360 & 0.344 & 0.926 & 0.420 & 0.854 & 0.447 & 0.707 & 1.258 & 0.860 & 0.514 & 1.089 & 1.121 & 1.071 & 0.358 \\
\hline & Limousin & 2.066 & 1.118 & 0.184 & 1.023 & 0.925 & 0.693 & 1.066 & 1.215 & 1.156 & 1.485 & 0.799 & 3.154 & 0.727 & 0.860 & 0.323 & 0.863 & 1.464 \\
\hline & Lorraine & 1.135 & 0.982 & 1.086 & 0.649 & 0.981 & 1.143 & 2.432 & 1.073 & 1.256 & 0.995 & 0.916 & 1.626 & 1.589 & 0.969 & 1.695 & 0.765 & 1.337 \\
\hline & Lang & 0.502 & 1.098 & 0.499 & 0.960 & 0.881 & 0.833 & 1.329 & 0.569 & 1.609 & 1.498 & 0.975 & 0.449 & 0.586 & 1.123 & 0.036 & 1.058 & 0.427 \\
\hline & Midi- & 1.715 & 1.076 & 0.548 & 0.898 & 0.843 & 1.323 & 0.301 & 0.607 & 1.325 & 1.287 & 0.875 & 0.821 & 1.484 & 0.908 & 1.683 & 0.998 & 0.683 \\
\hline & Nord-Pas- & 0.600 & 0.852 & 1.095 & 0.818 & 1.677 & 0.834 & 1.751 & 0.845 & 1.488 & 1.090 & 0.932 & 1.501 & 3.308 & 1.012 & 1.154 & 0.945 & 0.737 \\
\hline & Prov.-Alpe & 0.517 & 1.088 & 1.586 & 0.936 & 0.711 & 1.994 & 0.426 & 0.501 & 0.975 & 1.152 & 0.918 & 0.444 & 0.209 & 1.312 & 0.419 & 1.087 & 0.395 \\
\hline & Pays de la Loire & 1.668 & 1.154 & 0.262 & 0.992 & 1.648 & 0.831 & 0.312 & 1.098 & 0.811 & 1.151 & 0.939 & 0.802 & 1.116 & 0.929 & 0.872 & 0.942 & 1.477 \\
\hline & Picardie & 2.083 & 0.950 & 2.288 & 0.700 & 2.256 & 0.466 & 1.225 & 1.416 & 1.962 & 1.028 & 0.815 & 1.169 & 1.716 & 0.954 & 0.580 & 0.890 & 1.840 \\
\hline & Poito & 2.451 & 1.108 & 0.485 & 1.250 & 1.651 & 0.639 & 0.030 & 0.747 & 1.481 & 1.271 & 0.892 & 0.958 & 0.529 & 0.882 & 0.592 & 1.029 & 1.181 \\
\hline & Rhone-Alpes & 0.606 & 1.201 & 1.270 & 0.796 & 0.804 & 1.029 & 0.5 & 1.663 & 1.296 & 1.109 & 0.951 & 0.929 & 1.786 & 0.883 & 0.436 & 0.986 & 1.667 \\
\hline & avera & 1.457 & 1.061 & 1.014 & 0.880 & 1.242 & 0.924 & 1.446 & 1.036 & \begin{tabular}{ll|}
1.191 \\
\end{tabular} & 1.135 & 0.895 & \begin{tabular}{ll|}
1.088 \\
\end{tabular} & 1.020 & 0.966 & 1.010 & 0.969 & 1.298 \\
\hline & re & 12 & 0 & 3 & 0 & & 2 & 3 & 2 & 4 & 1 & $0(1$ & 5 & 5 & 0 & S & 0 & 5 \\
\hline & Bassin Parisien & 1.937 & 1.015 & 1.522 & 0.780 & $\begin{array}{l}1.473 \\
\end{array}$ & 1.069 & 2.975 & 1.341 & \begin{tabular}{ll|}
1.280 \\
\end{tabular} & 0.988 & 0.785 & 1.330 & 1.023 & 0.986 & 0.990 & 0.907 & 1.445 \\
\hline $\mathbf{N}$ & Centre-Est & 0.838 & 1.194 & 1.183 & 0.821 & 0.897 & 0.966 & 0.605 & 1.547 & 1.266 & 1.145 & 0.932 & 0.900 & 1.639 & 0.874 & 0.435 & 0.976 & 2.082 \\
\hline $\mathbf{U}$ & Est (F) & 0.920 & 0.999 & 1.223 & 0.71 & 1.224 & 0.757 & 1.327 & 1.326 & 1.355 & 0.948 & 0.972 & 1.425 & 1.527 & 0.853 & 1.995 & 0.836 & 1.479 \\
\hline $\mathbf{T}$ & Ile de F & 0.084 & 0.809 & 0.799 & 1.3 & 0.344 & 0.92 & 0.4 & 0.854 & 0.447 & 0.707 & 1.258 & 0.860 & 0.514 & 1.089 & 1.121 & 1.071 & 0.358 \\
\hline $\mathbf{s}$ & Médi & 0.542 & 1.101 & 1.219 & 0.938 & 0.747 & 1.622 & 0.676 & 0.506 & 1.161 & 1.268 & 0.936 & 0.435 & 0.313 & 1.253 & 0.296 & 1.086 & 0.399 \\
\hline & Nord-Pas-de-Calais & 0.600 & 0.852 & 1.095 & 0.818 & 1.677 & 0.834 & 1.7 & 0.845 & $1.4 \xi$ & 1.090 & 0.932 & 1.501 & 3.3 & & 1.154 & 0.945 & 0.737 \\
\hline 2 & Oues & 2.122 & 1.119 & 0.305 & 1.011 & 1.911 & 0.679 & 0.153 & 0.843 & 0.973 & 1.176 & 0.938 & 0.752 & 0.685 & 0.867 & 0.992 & 1.000 & 1.224 \\
\hline & Sud-1 & 1.936 & 1.120 & 0.801 & 0.917 & 0.910 & 1.189 & 0.276 & 0.701 & 1.129 & 1.286 & 0.858 & 1.208 & 0.910 & 0.956 & 1.092 & 1.027 & 0.958 \\
\hline & av & 1.122 & 1.026 & 1.018 & 0.920 & 1.148 & 1.005 & 1.023 & 0.995 & \begin{tabular}{ll|}
1.137 \\
\end{tabular} & $\begin{array}{l}1.076 \\
\end{array}$ & $\overline{0.951}$ & 1.051 & 1.240 & 0.986 & 1.009 & 0.981 & 1.085 \\
\hline & ni & & & & 011 & & & & & & $0(1$ & $0(1$ & & & $0(1)$ & & & \\
\hline
\end{tabular}

Note: Indices are averages for 1986-92. Box is shaded when the index reaches at least 1.5; box is cursive and bold when the sector turns out to be one of the two most important in the respective region even though the index does not reach 1.5 . 
Table A7: Specialisation indices for GFCF in Italian regions

\begin{tabular}{|c|c|c|c|c|c|c|c|c|c|c|c|c|c|c|c|c|c|c|}
\hline & & AGRO & BUIL & CHEM & CRED & JFOOD & TFUEL & TMETA & TMETP & TMINE & TNMSE & TOTHS & PAPE & TEXT & TRCO & TREQ & TRLO & IVAR \\
\hline \multirow{22}{*}{$\begin{array}{l}\mathbf{N} \\
\mathbf{U} \\
\mathbf{T} \\
\mathbf{S}\end{array}$} & Abruzzo & 1.368 & 0.758 & 0.447 & 0.643 & 1.059 & 1.235 & $\overline{0.404}$ & $\overline{1.068}$ & 1.351 & 1.008 & 1.065 & 1.924 & 0.725 & 0.641 & 2.135 & 0.697 & 0.886 \\
\hline & Basilicata & 2.145 & 1.635 & 0.774 & 0.528 & 1.358 & 1.349 & 0.165 & 0.382 & 0.650 & 2.176 & 0.955 & 0.225 & 0.199 & 0.512 & 1.308 & 0.423 & 0.399 \\
\hline & Calabria & 1.284 & 1.327 & 0.266 & 0.499 & 0.439 & 1.556 & 0.117 & 0.091 & 0.798 & 1.215 & 1.163 & 0.218 & 0.848 & 1.153 & 0.142 & 0.737 & 0.762 \\
\hline & Campania & 0.769 & 1.065 & 0.626 & 0.838 & 0.826 & 0.767 & 0.453 & 0.496 & 0.720 & 1.588 & 1.206 & 0.353 & 0.488 & 1.063 & 1.636 & 0.565 & 0.649 \\
\hline & Emilia-Romagna & 1.444 & 1.021 & 0.969 & 1.180 & 2.710 & 0.807 & 0.375 & 1.699 & 2.176 & 0.913 & 0.775 & 0.945 & 0.741 & 0.795 & 0.747 & 1.230 & 1.058 \\
\hline & Friuli-Venezia Giulia & 0.994 & 0.620 & 0.643 & 1.046 & 0.823 & 0.979 & 1.185 & 1.173 & 0.747 & 1.146 & 0.924 & 1.919 & 0.573 & 0.949 & 0.410 & 1.316 & 1.823 \\
\hline & Lazio & 0.491 & 1.135 & 0.779 & 1.231 & 0.484 & 1.149 & 0.126 & 0.451 & 0.508 & 0.653 & 1.076 & 1.043 & 0.117 & 1.946 & 0.808 & 1.015 & 0.322 \\
\hline & Liguria & 0.348 & 0.953 & 1.398 & 1.114 & 0.377 & 1.124 & 0.920 & 0.723 & 0.785 & 1.272 & 0.924 & 0.409 & 0.142 & 1.671 & 0.657 & 1.335 & 0.329 \\
\hline & Lombardia & 0.665 & 1.028 & 1.726 & 1.220 & 1.064 & 0.683 & 1.614 & 1.773 & 0.609 & 0.771 & 1.007 & 1.465 & 1.792 & 0.666 & 0.791 & 1.123 & 1.505 \\
\hline & Marche & 1.408 & 0.866 & 0.303 & 1.015 & 1.360 & 0.533 & 0.334 & 1.139 & 0.747 & 1.087 & 1.056 & 1.002 & 1.619 & 0.753 & 0.446 & 1.036 & 1.799 \\
\hline & Molise & 1.944 & 1.226 & 0.613 & 0.587 & 0.913 & 1.338 & 1.108 & 0.211 & 1.379 & 1.023 & 1.160 & 0.014 & 0.497 & 0.496 & 4.130 & 0.378 & 0.362 \\
\hline & Piemonte & 0.976 & 0.765 & 0.953 & 1.042 & 1.018 & 0.823 & 1.870 & 1.584 & 0.896 & 0.721 & 0.824 & 1.127 & 1.342 & 1.171 & 3.845 & 0.750 & 1.168 \\
\hline & Puglia & 1.403 & 0.952 & 0.566 & 0.811 & 0.866 & 1.684 & 2.062 & 0.521 & 0.948 & 1.008 & 1.170 & 0.299 & 0.607 & 0.638 & 0.548 & 0.693 & 0.732 \\
\hline & Sardegna & 1.458 & 0.829 & 2.065 & 0.601 & 0.624 & 2.330 & 1.460 & 0.152 & 1.170 & 1.254 & 0.908 & 0.173 & 0.944 & 0.749 & 0.097 & 1.000 & 0.487 \\
\hline & Sicilia & 1.235 & 1.186 & 0.699 & 0.696 & 0.405 & 1.715 & 0.244 & 0.221 & 1.063 & 1.358 & 1.275 & 0.241 & 0.240 & 0.709 & 0.447 & 0.640 & 0.246 \\
\hline & Trentino-Alto Adige & 1.376 & 0.974 & 0.257 & 0.763 & 1.223 & 0.586 & 0.886 & 0.553 & 0.724 & 1.408 & 0.809 & 0.868 & 0.244 & 0.863 & 0.313 & 2.309 & 1.440 \\
\hline & Toscana & 1.093 & 0.996 & 1.137 & 1.177 & 0.611 & 0.992 & 1.212 & 0.614 & 1.967 & 1.002 & 0.857 & 1.618 & 1.798 & 0.984 & 0.509 & 1.334 & 1.011 \\
\hline & Umbria & 1.414 & 0.626 & 0.884 & 0.853 & 1.950 & 1.221 & 3.593 & 0.504 & 2.176 & 0.858 & 0.957 & 0.839 & 1.042 & 0.912 & 0.264 & 0.840 & 0.779 \\
\hline & Valle d'Aosta & 0.926 & 1.026 & 0.164 & 0.467 & 0.450 & 0.790 & 1.583 & 0.213 & 0.825 & 3.282 & 0.974 & 0.090 & 0.029 & 1.071 & 0.023 & 0.620 & 0.190 \\
\hline & Veneto & 1.172 & 0.955 & 1.005 & 0.953 & 1.202 & 0.607 & 0.851 & 1.316 & 1.182 & 0.847 & 0.937 & 1.471 & 1.785 & 0.982 & 0.372 & 1.065 & 1.697 \\
\hline & average & 1.196 & 0.997 & 0.814 & 0.863 & 0.988 & 1.113 & 1.028 & 0.744 & 1.071 & 1.230 & 1.001 & 0.812 & 0.789 & 0.936 & 0.981 & 0.955 & 0.882 \\
\hline & number of spec. regions & 2 & 1 & 2 & & 2 & 4 & 5 & 3 & 3 & 3 & & 3 & 4 & 2 & 4 & 1 & 5 \\
\hline \multirow{13}{*}{$\begin{array}{l}\mathbf{N} \\
\mathrm{U} \\
\mathbf{T} \\
\mathrm{S} \\
\\
2\end{array}$} & Abruzzo-Molise & 1.503 & 0.875 & 0.484 & 0.625 & 1.021 & 1.262 & 0.534 & 0.881 & 1.327 & 1.007 & 1.082 & 1.491 & 0.669 & 0.610 & 2.687 & 0.622 & 0.763 \\
\hline & Campania & 0.769 & 1.065 & 0.626 & 0.838 & 0.826 & 0.767 & 0.453 & 0.496 & 0.720 & 1.588 & 1.206 & 0.353 & 0.488 & 1.063 & 1.636 & 0.565 & 0.649 \\
\hline & Centro (I) & 1.221 & 0.908 & 0.888 & 1.087 & 1.004 & 0.910 & 1.353 & 0.730 & 1.693 & 1.001 & 0.922 & 1.342 & 1.637 & 0.915 & 0.455 & 1.186 & 1.176 \\
\hline & Emilia-Romagna & 1.444 & 1.021 & 0.969 & 1.180 & 2.710 & 0.807 & 0.375 & 1.699 & 2.176 & 0.913 & 0.775 & 0.945 & 0.741 & 0.795 & 0.747 & 1.230 & 1.058 \\
\hline & Lazio & 0.491 & 1.135 & 0.779 & 1.231 & 0.484 & 1.149 & 0.126 & 0.451 & 0.508 & 0.653 & 1.076 & 1.043 & 0.117 & 1.946 & 0.808 & 1.015 & 0.322 \\
\hline & Lombardia & 0.665 & 1.028 & 1.726 & 1.220 & 1.064 & 0.683 & 1.614 & 1.773 & 0.609 & 0.771 & 1.007 & 1.465 & 1.792 & 0.666 & 0.791 & 1.123 & 1.505 \\
\hline & Nord Est & 1.175 & 0.898 & 0.806 & 0.933 & 1.135 & 0.671 & 0.919 & 1.153 & 1.022 & 1.005 & 0.910 & 1.447 & 1.291 & 0.956 & 0.367 & 1.334 & 1.672 \\
\hline & Nord Ovest & 0.815 & 0.822 & 1.031 & 1.038 & 0.834 & 0.896 & 1.624 & 1.315 & 0.866 & 0.959 & 0.853 & 0.907 & 0.991 & 1.298 & 2.892 & 0.892 & 0.920 \\
\hline & Sardegna & 1.458 & 0.829 & 2.065 & 0.601 & 0.624 & 2.330 & 1.460 & 0.152 & 1.170 & 1.254 & 0.908 & 0.173 & 0.944 & 0.749 & 0.097 & 1.000 & 0.487 \\
\hline & Sicilia & 1.235 & 1.186 & 0.699 & 0.696 & 0.405 & 1.715 & 0.244 & 0.221 & 1.063 & 1.358 & 1.275 & 0.241 & 0.240 & 0.709 & 0.447 & 0.640 & 0.246 \\
\hline & Sud & 1.448 & 1.153 & 0.490 & 0.673 & 0.780 & 1.605 & 1.192 & 0.365 & 0.866 & 1.212 & 1.141 & 0.262 & 0.643 & 0.793 & 0.543 & 0.675 & 0.702 \\
\hline & average per sector & 1.111 & 0.993 & 0.960 & 0.920 & 0.990 & 1.163 & 0.900 & 0.840 & 1.093 & 1.066 & 1.014 & 0.879 & 0.868 & 0.954 & 1.043 & 0.935 & 0.864 \\
\hline & number of spec. regions & $\overline{1}$ & & 2 & & 1 & 3 & 2 & $\overline{2}$ & $\overline{2}$ & 1 & & & $\overline{2}$ & 1 & 3 & & $\overline{2}$ \\
\hline
\end{tabular}

Note: Indices are averages for 1985-94. Box is shaded when the index reaches at least 1.5; box is cursive and bold when the sector turns out to be one of the two most important in the respective region even though the index does not reach 1.5. 
Table A8: Specialisation indices for GFCF in Belgian regions

\begin{tabular}{|c|c|c|c|c|c|c|c|c|c|c|c|c|}
\hline & & BUIL & CHEM & FOOD & FUEL & META & METP & MINE & PAPE & TEXT & TREQ & VARI \\
\hline \multirow{13}{*}{$\begin{array}{l}N \\
U \\
T \\
S \\
1\end{array}$} & Antwerpen & 0.065 & 0.952 & 0.197 & 0.473 & 0.140 & 0.133 & 0.211 & 0.254 & 0.022 & 0.173 & 0.142 \\
\hline & Région Bruxelles-capitale & 0.026 & 0.073 & 0.081 & 0.849 & 0.012 & 0.057 & 0.025 & 0.170 & 0.019 & 0.112 & 0.015 \\
\hline & Brabant Wallon & 0.057 & n.a. & 0.182 & n.a. & 0.113 & 0.085 & 0.074 & 0.338 & 0.019 & n.a. & 0.052 \\
\hline & Hainaut & 0.059 & 0.259 & 0.091 & 0.124 & 0.179 & 0.165 & 0.756 & 0.153 & 0.118 & 0.040 & 0.081 \\
\hline & Liège & 0.073 & \begin{tabular}{|l|l|}
0.142 \\
\end{tabular} & 0.358 & 0.215 & 0.460 & 0.161 & 0.287 & 0.151 & 0.051 & n.a. & 0.217 \\
\hline & Limburg (B) & 0.092 & 0.291 & 0.178 & 0.140 & 0.368 & 0.221 & 0.368 & 0.623 & 0.093 & 0.696 & 0.310 \\
\hline & Luxembourg (B) & 0.109 & n.a. & 0.261 & n.a. & 0.000 & 0.036 & 0.095 & n.a. & n.a. & n.a. & 0.498 \\
\hline & Namur & 0.068 & n.a. & 0.137 & 0.152 & n.a. & 0.053 & 0.941 & 0.113 & n.a. & 0.007 & 0.138 \\
\hline & Oost-Vlaanderen & 0.097 & 0.166 & 0.291 & 0.154 & 0.350 & 0.089 & 0.085 & 0.304 & 0.500 & 0.154 & 0.323 \\
\hline & Vlaams Brabant & 0.056 & 0.225 & 0.315 & 0.256 & 0.009 & 0.109 & 0.108 & 0.420 & 0.024 & 0.230 & 0.155 \\
\hline & West-Vlaanderen & 0.083 & 0.111 & 0.267 & 0.124 & 0.110 & 0.206 & 0.255 & 0.255 & 0.767 & 0.026 & 0.347 \\
\hline & average per sector & 0.071 & 0.277 & 0.214 & 0.276 & 0.174 & 0.120 & 0.291 & 0.278 & 0.179 & 0.180 & 0.207 \\
\hline & number of spec. regions & & 2 & 4 & 3 & 2 & & 2 & 4 & 2 & 1 & 2 \\
\hline $\mathbf{N}$ & Région Bruxelles-capitale & 0.026 & 0.073 & 0.081 & 0.849 & 0.012 & 0.057 & 0.025 & 0.170 & 0.019 & 0.112 & 0.015 \\
\hline $\mathbf{U}$ & Région Wallone & 0.069 & 0.240 & 0.208 & 0.142 & 0.484 & 0.133 & 0.511 & 0.330 & 0.059 & 0.021 & 0.160 \\
\hline $\mathbf{T}$ & Vlaams Gewest & 0.078 & 0.439 & 0.245 & 0.266 & 0.194 & 0.145 & 0.197 & 0.325 & 0.279 & 0.245 & 0.243 \\
\hline S & average per sector & 0.057 & 0.251 & 0.178 & 0.419 & 0.230 & 0.111 & 0.244 & 0.275 & 0.119 & 0.126 & 0.139 \\
\hline 2 & number of spec. regions & & 1 & & 1 & 1 & & & 3 & & & \\
\hline
\end{tabular}

Note: Indices are averages for 1985-94. The two most important sectors are marked for each region - the specialisation index represents the region's investment share in the respective sector in relation to the sector's share in national gross value added. 
Table A9: Specialisation indices for British NUTS 1-regions (Lorenz-Münzner-coefficients)

\begin{tabular}{|c|c|c|c|c|c|c|c|c|c|c|}
\hline & & agro & food & fuel & meta & metp & pape & trco & treq & vari \\
\hline \multirow{6}{*}{$\begin{array}{l}\mathbf{N} \\
\mathbf{U} \\
\mathbf{T} \\
\mathrm{S}\end{array}$} & East Anglia & 1.516 & 1.883 & 1.056 & 0.370 & 0.869 & 0.945 & 0.817 & 0.281 & $\overline{1.471}$ \\
\hline & East Midlands & 1.052 & 1.460 & 0.994 & 1.505 & 1.094 & 0.853 & 0.841 & 0.710 & 1.176 \\
\hline & Northern Ireland & 5.740 & 1.406 & 0.669 & 0.881 & 0.552 & 0.443 & 1.161 & 0.437 & 0.774 \\
\hline & Scotland & 2.962 & 1.128 & 1.632 & 1.033 & 1.371 & 1.147 & 1.100 & 0.470 & 1.048 \\
\hline & South West & 1.141 & 1.153 & 0.695 & 0.812 & 0.760 & 0.813 & 0.950 & 1.132 & $\overline{1.121}$ \\
\hline & Wales & 2.280 & 1.013 & 0.907 & 3.718 & 1.149 & 0.812 & 0.645 & 0.775 & $\overline{1.313}$ \\
\hline \multirow[t]{2}{*}{1} & West Midlands & 0.652 & 0.883 & 0.755 & 1.676 & 1.655 & 0.606 & 0.940 & 2.868 & 1.473 \\
\hline & Yorkshire and the Humber & 0.826 & 1.292 & 1.510 & 1.835 & 0.865 & 0.715 & 0.814 & 0.387 & 1.048 \\
\hline & average per sector & 2.021 & (1.277 & $\overline{1.027}$ & $\overline{c 1.479}$ & 1.039 & 0.792 & 0.908 & 0.882 & $\overline{1.178}$ \\
\hline & number of spec. regions & $4(5)$ & $1(4)$ & 2 & 4 & 1 & & & 1 & \\
\hline
\end{tabular}

Note: Indices are averages for 1985-87. Box is shaded when the index reaches at least 1.5; box is in italics and bold type when the sector turns out to be one of the two most important in the respective region even though the index does not reach 1.5. 
Table A10: Concentration of GFCF in EU regions in 1985 to 1994 (Lorenz-Münzner-coefficients/ 17 sectors)

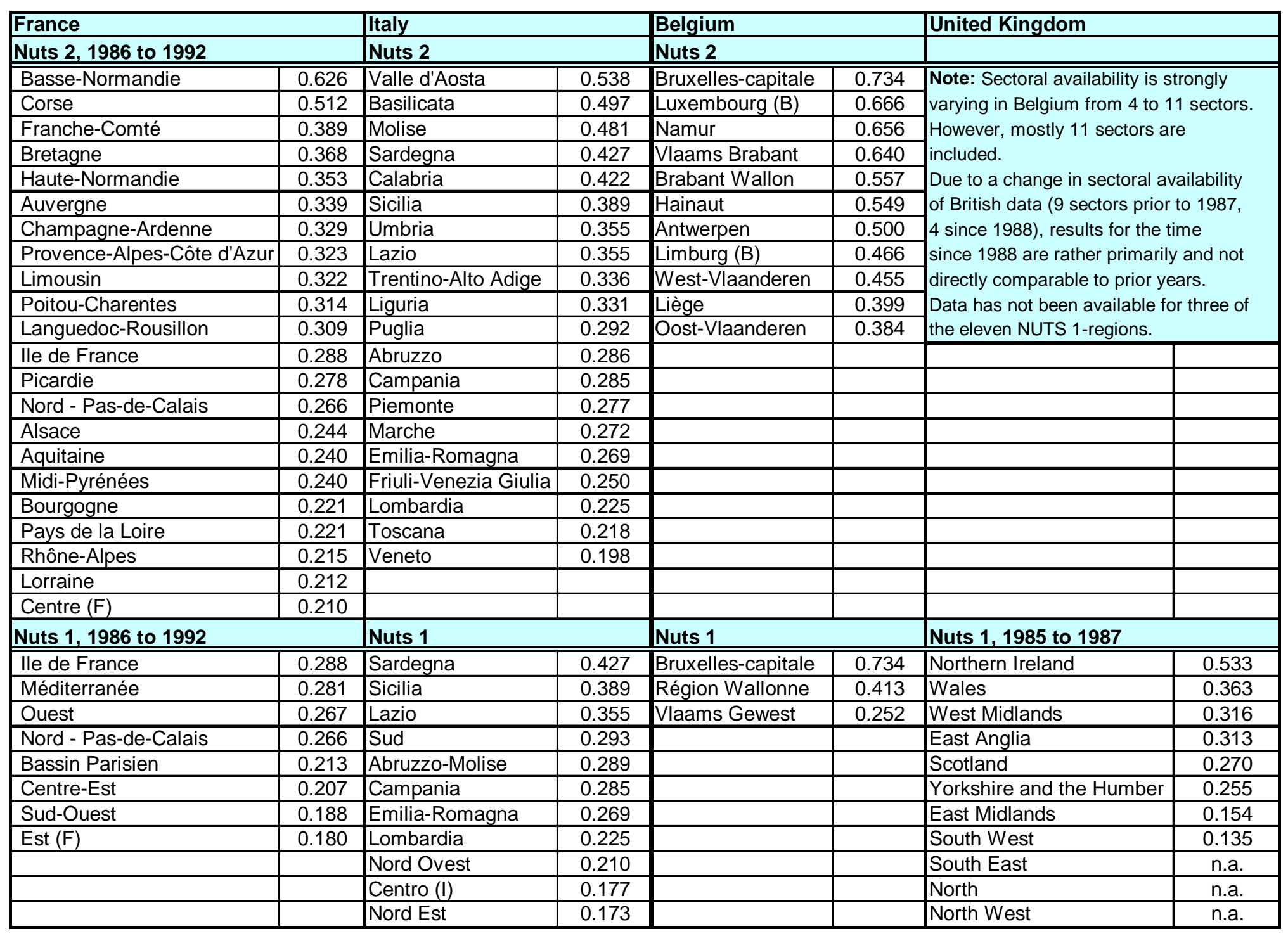


Table A11: Characteristics of most/least concentrated NUTS 2-regions (average 1985-94 unless indicated in brackets)

\begin{tabular}{|c|c|c|c|c|c|c|c|c|c|}
\hline Region & $\begin{array}{l}\text { Index of } \\
\text { capital con- } \\
\text { centration }\end{array}$ & $\begin{array}{l}\text { Index of em- } \\
\text { ployment } \\
\text { concentration }\end{array}$ & $\begin{array}{l}\text { Regional } \\
\text { per capita } \\
\text { GDP in } \\
\text { Mio ECU } \\
\text { per } 1000\end{array}$ & $\begin{array}{l}\text { GFCF in billion } \\
\text { ECU }\end{array}$ & $\begin{array}{l}\text { GFCF } \\
\text { in } \% \text { of } \\
\text { GDP }\end{array}$ & $\begin{array}{l}\text { Num- } \\
\text { ber of } \\
\text { patents } \\
\text { [89-94] }\end{array}$ & $\begin{array}{l}\text { Employ- } \\
\text { ment } \\
\text { share } \\
(\text { in\%) }\end{array}$ & $\begin{array}{l}\text { Unemploy- } \\
\text { ment rate } \\
\text { (in \% of } \\
\text { working } \\
\text { population) }\end{array}$ & $\begin{array}{l}\text { Net migra- } \\
\text { tion rate } \\
1997 \text { in \% of } \\
\text { population }\end{array}$ \\
\hline \multicolumn{10}{|c|}{ NUTS 2, Most concentrated regions } \\
\hline Bruxelles-capitale & 0.734 & $0.503[85-92]$ & 23.17 & n.a. & n.a. & 71 & 18.0 & 10.82 & 0.1 \\
\hline Basse-Normandie & $0.626[86-92]$ & $0.345[85-89]$ & 13.15 & $4.25[86-92]$ & 24.22 & 59 & 2.5 & 9.87 & 0.4 \\
\hline Corsica & $0.512[86-92]$ & $0.492[85-89]$ & 12.40 & 0.58 [86-92] & 19.26 & n.a. & 0.4 & 11.18 & 3.1 \\
\hline Valle d'Aosta & 0.538 & 0.525 & 17.36 & 0.67 & 33.83 & 2 & 0.3 & 3.95 & 5.4 \\
\hline Basilicata & 0.500 & 0.591 & 8.62 & 1.46 & 28.0 & 1 & 0.9 & 16.67 & 3.1 \\
\hline \multicolumn{10}{|c|}{ Least concentrated regions } \\
\hline Centre (F) & $0.21[86-92]$ & $0.287[85-89]$ & 14.53 & 6.83 [86-92] & 20.2 & 147 & 4.2 & 9.63 & 2.0 \\
\hline Toscana & 0.218 & 0.350 & 14.63 & 8.36 & 16.2 & 119 & 6.7 & 7.56 & 4.9 \\
\hline Veneto & 0.198 & 0.356 & 15.48 & 13.05 & 20.2 & 223 & 8.7 & 5.55 & 4.0 \\
\hline \multicolumn{10}{|c|}{ Region including national capital } \\
\hline Ile de France & $0.288[86-92]$ & $0.247[85-89]$ & 24.30 & 52.07 [86-92] & 20.61 & 2232 & 22.6 & 8.29 & -4.9 \\
\hline Lazio & 0.355 & $0.314[85-91]$ & 15.18 & 16.63 & 21.24 & 147 & 9.3 & 9.75 & 5.2 \\
\hline South-East & n.a. & n.a. & 15.08 & n.a. & n.a. & 779 & 33.8 & 7.86 & 25.0 \\
\hline
\end{tabular}


Table A12: Characteristics of most/least concentrated NUTS 1 regions (average 1985-94 unless indicated in brackets)

\begin{tabular}{|c|c|c|c|c|c|c|c|c|c|}
\hline Region & $\begin{array}{l}\text { Index of } \\
\text { capital con- } \\
\text { centration }\end{array}$ & $\begin{array}{l}\text { Index of em- } \\
\text { ployment } \\
\text { concentration }\end{array}$ & $\begin{array}{l}\text { Regional } \\
\text { per capita } \\
\text { GDP in } \\
\text { Mio ECU } \\
\text { per } 1000 \\
\end{array}$ & $\begin{array}{l}\text { GFCF in billion } \\
\text { ECU }\end{array}$ & $\begin{array}{l}\text { GFCF } \\
\text { in \% of } \\
\text { GDP }\end{array}$ & \begin{tabular}{|l} 
Num- \\
ber of \\
patents \\
{$[89-94]$}
\end{tabular} & $\begin{array}{l}\text { Employ- } \\
\text { ment } \\
\text { share } \\
\text { (in\%) }\end{array}$ & $\begin{array}{l}\text { Unemploy- } \\
\text { ment rate } \\
\text { (in \% of } \\
\text { working } \\
\text { population) }\end{array}$ & $\begin{array}{l}\text { Net migra- } \\
\text { tion rate } \\
1997 \text { in \% of } \\
\text { population }\end{array}$ \\
\hline Bruxelles-capitale & 0.734 & 0.503 [85-92] & 23.17 & n.a. & n.a. & 71 & 18.0 & 10.82 & 0.1 \\
\hline Région Wallonne & 0.413 & $0.295[85-92]$ & 11.96 & n.a. & n.a. & 137 & 27.6 & 11.53 & 1.2 \\
\hline Sardegna & 0.427 & 0.450 & 10.07 & 4.18 & 25.40 & 8 & 2.4 & 17.87 & -1.0 \\
\hline Sicilia & 0.315 & 0.518 & 9.09 & 9.53 & 20.98 & 36 & 6.9 & 17.85 & -0.6 \\
\hline Northern Ireland & $0.533[85-87]$ & n.a. & 35.32 & $1.82[88-93]$ & 10.89 & n.a. & 2.4 & 16.73 & n.a. \\
\hline Wales & $0.363[85-87]$ & n.a. & 16.99 & 3.67 [88-93] & 11.29 & 55 & 4.4 & 10.16 & -74.7 \\
\hline Est $(F)$ & 0.180 [86-92] & 0.239 [85-89] & 14.40 & 15.76 [86-92] & 22.21 & 415 & 8.4 & 8.26 & -1.8 \\
\hline Centro (I) & 0.177 & 0.358 & 14.22 & 14.04 & 17.13 & 170 & 11.0 & 7.38 & 4.9 \\
\hline Nord Est (I) & 0.173 & 0.329 & 15.59 & 20.31 & 20.20 & 335 & 12.9 & 5.54 & 3.9 \\
\hline South West & $0.135[85-87]$ & n.a. & 6.52 & $5.51[88-93]$ & 9.20 & 125 & 7.9 & 7.86 & 6.3 \\
\hline East Midlands & $0.154[85-87]$ & n.a. & 3.95 & 5.12 [88-93] & 9.86 & 131 & 6.7 & 8.49 & 6.7 \\
\hline
\end{tabular}

